\title{
ANLAŞMALI BOŞANMA PROTOKOLÜNÜN TAŞINMAZLAR ÜZERİNDEKİ AYNÎ HAKLARA İLİŞKINN HÜKÜMLERİ İLE İLGİLİ BAZI HUKUKI SORUNLAR
}

\author{
Arş. Gör. Dr. Feride DEMİRBAŞ ${ }^{*}$
}

\section{ÖZET}

Anlaşmalı boşanma, evlilik birliğini sürdüremeyen eşlerin daha hızlı ve kolay biçimde boşanmalarını sağlayan bir yargılama faaliyetidir. Eşler arasında belirli içerik ve nitelikte akdedilen bir anlaşmanın hâkim tarafından uygun bulunması ile boşanma ve anlaşmada kararlaştırılan konular hakkında istenen hukuki sonuca ulaşılabilmektedir. Eşler arasında "boşanma protokolü” olarak adlandırılan anlaşmanın, eşlerden birine ait bir taşınmazın mülkiyetinin diğer eşe veya üçüncü kişiye devrini ya da taşınmaz üzerinde sınırlı ayni hak tesis edilmesini içeren hükümleri bulunabilir. Bu takdirde ayni hakkın kazanılıp kazanılmaması ve kazanılma zamanı, protokolün hâkim tarafından ne şekilde uygun bulunmuş olduğuna göre farklılık taşımaktadır. Protokol hükümlerinin boşanma hükmünün içeriğine dâhil olma biçimi, hukuki sürecin sonraki aşamalarını doğrudan etkilemektedir. Çoğu zaman ayni hakkın elde edilebilmesi, ikinci bir davanın açılmasını gerektirmektedir. Bu çalışmanın amacı, boşanma protokolünün boşanma kararı ile ilişkisini, protokolde ayni haklara ilişkin yükümlülüklerin yerine getirilmemesinin hukuki sonuçlarını tespit etmek, konuya ilişkin yargı uygulamasındaki bir takım aksaklıklara işaret ederek hukuki çözümler önermektir.

Anahtar Kelimeler: Boşanma, anlaşmalı boşanma, boşanma protokolü, tescil, görevli mahkeme, yetkili mahkeme.

Akdeniz Üniversitesi Hukuk Fakültesi, Medeni Hukuk Anabilim Dalı, feridedemirbas@gmail.com, ORCID ID: 0000-0002-4774-343X (Geliş Tarihi: 24.03.2020 Kabul Tarihi: 23.05.2020). 


\title{
SOME LEGAL PROBLEMS RELATING TO THE PROVISIONS OF THE DIVORCE AGREEMENT ABOUT THE REAL RIGHTS ON THE IMMOVABLE PROPERTY
}

\begin{abstract}
Consensual divorce is a judicial activity that allows spouses to divorce more quickly and easily to those who cannot continue their union of marriage. By the judge's approval of the agreement between the spouses which is certain content and quality, the desired legal conclusion can be reached about the issues decided in the divorce and agreement. The divorce agreement between the spouses may comprise provisions that include the transfer of ownership of one of the spouses' property to the other spouse or third party or the establishment of limited real rights on the property. In this case, whether or not the real right to be entitled and the time to be entitled differs according to how the agreement was approved by the judge. The way the agreement provisions are included in the content of the divorce provision directly affects the later stages of the legal process. Most of the time, the entitling of the real right requires a second lawsuit to be filed. The purpose of this study is to determine the relationship between the divorceagreement and the divorce decision and the legal consequences of not fulfilling the obligations related to real rights in the divorce agreement and to suggest legal solutions by pointing out some flaws in the judicial practice on the subject.
\end{abstract}

Keywords: Divorce, the divorce by joint request, divorce agreement, land registration, competent court, authorized court. 


\section{ANLAŞMALI BOŞANMA HAKKINDA GENEL BİLGİLER}

Hukuk sistemlerinin, hızlı bir biçimde değişen ve dönüşen toplumsal hayatın ihtiyaçlarına cevap vermesi gerekmektedir. Bu ihtiyaçların bir bölümü de aile hukukuna, evlilik birliğine ve bu birliğin sona erdirilmesine ilişkin olarak ortaya çıkmaktadır. Bu bağlamda ilk kez 1988 yılında 3444 sayılı Kanun ile Türk hukukuna giren, sonrasında 4721 sayılı Türk Medeni Kanunu'nun ${ }^{1}$ 166. maddesinin üçüncü fikrası ile varlığını sürdüren anlaşmalı boşanma müessesesi ile evlilik birliğini devam ettirmek istemeyen eşlere daha kolay ve hızlı biçimde boşanma imkânı tanınmıştır² .

Anlaşmalı boşanmanın düzenlendiği TMK m. 166/3 uyarınca "Evlilik en az bir yıl sürmüş ise, eşlerin birlikte başvurması ya da bir eşin diğerinin davasını kabul etmesi hâlinde, evlilik birliği temelinden sarsılmış sayılır. Bu hâlde boşanma kararı verilebilmesi için, hâkimin tarafları bizzat dinleyerek iradelerinin serbestçe açıklandiğına kanaat getirmesi ve boşanmanın malî sonuçları ile çocukların durumu hususunda taraflarca kabul edilecek düzenlemeyi uygun bulması şarttır. Hâkim, tarafların ve çocukların menfaatlerini göz önünde tutarak bu anlaşmada gerekli gördüğü değişiklikleri yapabilir. Bu değiş̧ikliklerin taraflarca da kabulü hâlinde boşanmaya hükmolunur. Bu hâlde tarafların ikrarlarının hâkimi bağlamayacağı hükmü uygulanmaz.”. Bu hüküm ile eşlerin belirli koşullar içinde mahkemeye başvurması veya eşlerden birinin açtığı davayı diğerinin kabul etmesi halinde evlilik birliği temelinden sarsılmış varsayılır ${ }^{3}$ ve hâkim boşanmaya karar verir.

\footnotetext{
RG. T: 8.12.2001, S:24607.
}

2 İsviçre'de anlaşmalı boşanma müessesi İsviçre Medeni Kanunu'nda daha farklı bir sistematikte düzenlenmiştir. İMK m. $111 \mathrm{vd}$. maddeleri uyarınca eşlerin boşanma ve boşanmanın sorumları üzerinde tam veya kısmi olarak anlaşmalarına göre, uygulanacak usulün değiştiği bir boşanma modeli öngörülmüştür. Konu hakkında ayrıntılı açıklamalar için bkz. Schwenzer, Ingeborg/Fankhauser, Roland (2017) Scheidung Band II: Anhänge, 3. Auflage, Stämpfli Verlag, Bern, s. 541 vd.

3 Öztan, Bilge (2015) Aile Hukuku, 6. Bası, Turhan Kitabevi, Ankara, s.693; Dural, Mustafa/Öğüz, Tufan/Gümüş, Mustafa Alper (2019) Türk Özel Hukuku Cilt III Aile Hukuku, 14. Bası, Filiz Kitabevi, İstanbul, N. 647; Kılıçoğlu, Ahmet M. (2015), Aile Hukuku, Turhan Kitabevi, Ankara, s. 141-142; Akıntürk, Turgut/Ateş, Derya (2018) Türk Medeni Hukuku Aile Hukuku İkinci Cilt, Beta Yayınevi, İstanbul, s. 269. 
Eşlerin bir an önce evlilik birliğini sona erdirmelerine imkân veren anlaşmalı boşanma, onların kusurlu olup olmamalarına ilişkin değerlendirmelerden bağımsızdır. Kanunda yer alan koşulların gerçekleşmesi ile boşanma kararı verilebilir.

Hâkimin anlaşmalı boşanmaya karar verebilmesi için gereken koşullardan ilki evliliğin en az bir yıl sürmüş olmasıdır ${ }^{4}$. Bir yıllık süre evlilik tarihinden itibaren işlemeye başlar ve eşlerin bu süre zarfında fiilen bir arada yaşamaları şartı aranmaz ${ }^{5}$.

Evli kişilerin anlaşmalı olarak boşanabilmesi için eşlerin boşanmayı birlikte talep etmeleri veya bir eşin açtığ etmesi gerekir. Bu iki durumda, diğer koşulların da gerçekleşmesiyle hâkim, evlilik birliğinin temelinden sarsılıp sarsılmadığını araştırmaz ${ }^{6}$.Öğretide iki kişinin aynı anda hem davalı hem de davacı olmasının mümkün olmaması sebebiyle, başvurulabilecek yolun eşlerden birinin açtı̆̆ 1 davayı diğerinin kabul etmesi olduğu ileri sürülmektedir ${ }^{7}$. Fakat bu görüş azınlıkta kalmakta ve kanunun açık lafzı nedeniyle eşlerin birlikte başvurmasının mümkün ve yürütülen yargı faaliyetinin bir çekişmesiz yargı faaliyeti olduğ ${ }^{8}$; bu nedenle,

4 Bir yıllık sürenin hukuki niteliğinin dava şartı olduğu hususunda bkz. Yargıtay 2. Hukuk Dairesi, E: 2003/2269, K: 2003/3453, T: 13.03.2003, karar metni için bkz. $<$ https://www.lexpera.com.tr/ictihat/yargitay/2-hukuk-dairesi-e-2010-13750-k-2011-13266t-13-9-2011> s.e.t: 22.07.2019. Dava açıldıktan sonra 1 yıllık sürenin durması halinde davanın reddedilmeyip yargılamaya devam edilmesi yönünde bkz. Öztan, s. 694; Yılmaz Bilgin, Esra Pınar (2016) Türk Hukukunda Anlaşmalı Boşanma, On İki Levha Yayıncılık, İstanbul, s. 38.

5 Dural/Öğüz/Gümüş, N. 648-649; Özdemir, Nevzat (2003) "Türk Hukukunda Anlaşmalı Boşanma” (Doktora), İstanbul Üniversitesi Sosyal Bilimler Enstitüsü, s. 148.

6 Özdemir, s. 155.

7 Kılıçoğlu, s. 143. Aynı soruna işaret eden fakat yargılama hukuku bakımından bu sorunun çözümünü imkansız olarak nitelendirmeyen görüş için bkz. Akıntürk/Ateş, s. 270.

8 Akkaya, Tolga (2017) Medeni Usul Hukuku Bakımından Boşanma Davası, Yetkin Yayınları, Ankara, s. 245. Yazar anlaşmalı boşanmada kural olarak basit yargılama usulünün uygulanması gerektiğini belirtmektedir. Adi çekişmesiz yargı işlerinde (ve bu bağlamda anlaşmalı boşanmada) yazılı yargılama usulünün uygulanması gerektiği yönünde bkz. Budak, Ali Cem/Karaaslan, Varol (2017) Medeni Usul Hukuku, Adalet Yayınevi, Ankara, $\$ 21$, N. 30. Öğretide Özdemir eşlerin birlikte başvurmaları halinde de, bir eşin açtığı davayı diğerinin kabul etmesi halinde kabulden itibaren yürütülen faaliyetin bir 
birlikte başvuruda bulunan eşlerin "davacı" ve "davalı" olarak değil de "birlikte boşanma talep eden ilgililer" olarak adlandırılmaları gerektiği belirtilmektedir ${ }^{9}$. Eşlerden birinin açtığı davayı diğerinin kabul etmesi halinde de, diğer şartların gerçekleşmesi koşuluyla boşanmaya karar verilebilir ${ }^{10}$. Bu olasılıkta bahsi geçen "kabul" ile davayı sona erdiren dar ve teknik anlamdaki “davayı kabul”ün kast edilmediği; boşanma kararının verilebilmesi için varlığı gerekli olan bir irade açıklaması olarak "boşanma talebini kabul”ün anlaşılması gerektiği ileri sürülmektedir ${ }^{11}$. Nitekim dar ve teknik anlamda davayı kabul işlemi geri alınmamaktadır. Ancak Yargıtay’a göre eşler, temyiz aşamasında dahi anlaşmalı boşanma talebinden vazgeçebilmektedir ${ }^{12} . \mathrm{Bu}$ olasılıkta anlaşmalı boşanma davası çekişmeli olarak görülmeye devam eder ${ }^{13}$.

Anlaşmalı boşanmanın gerçekleşebilmesi için gereken bir diğer şart da hâkimin eşleri bizzat dinlemesidir. Hâkim, eşlerin boşanmaya özgür iradeleri ile karar verip vermediklerini bu sayede tespit eder. Eşlerin dinlenilmesi aynı

çekişmesiz yargı işi olduğunu ve basit yargılama usulünün uygulanması gerektiğini belirtmektedir. Bkz. Özdemir, s. 157-159.

9 Akkaya, s. 247. İsviçre hukukunda anlaşmalı boşanma yargılamasının taraflarının "başvuranlar" olarak adlandırılmasına ilişkin öneri hakkında bkz. Schwenzer/Fankhauser, s. 550, N. 12.

10 Öğretide "eşlerden birinin açtığı dava"nın TMK m. 166/I hükmüne dayanma zorunluluğu olmadığ1 yönünde bkz. Dural/Öğüz/Gümüsş, N. 650-151; Seçer, s. 261. Akıl hastalı̆̆1 haricindeki bir nedenle açılan boşanma davasının diğer eş tarafından kabul edilmesi halinde de TMK m. 166/III hükmü uygulama alanı bulur. Bkz. Özdemir, s. 171.

11 Akkaya, s. 248. Aynı yönde bkz. Yargitay Hukuk Genel Kurulu, E: 2017/2-1941, K: 2019/475, T: 18.4.2019, karar metni için bkz.<https://karararama.yargitay.gov.tr/YargitayBilgiBankasiIstemciWeb/> s.e.t: 01.08.2019.

12 Bkz. Yargitay Hukuk Genel Kurulu, E: 2017/1941, K: 2019/475, T: 18.04.2019, karar metni için bkz. <https://karararama.yargitay.gov.tr> s.e.t: 23.01.2020; Yargitay 2. Hukuk Dairesi, E: 2016/24006, K: 2018/10507, T: 3.10.2018, karar metni için bkz. <https://www.lexpera.com.tr/ictihat/yargitay/2-hukuk-dairesi-e-2016-24006-k-2018-10507t-3-10-2018> s.e.t: 24.07.2019. Öğretide yargılamanın her aşamasında kabul beyanının geri alınabilmesi yönündeki uygulama eleştirilmektedir. Hüküm verildikten sonra bu iradeden dönülememesi gerektiği savunulmaktadır. Bkz. Akkaya, s. 250-251. Kararın şekli anlamda kesinleşmesine kadar kabulden dönülebileceği yönünde bkz. Özdemir, s. 176. 
veya farklı celselerde gerçekleşebilir ${ }^{14}$. Eşlerin anlaşmalı olarak boşanma iradelerini temsilci aracılığıyla değil, bizzat ifade etmeleri gerekmektedir ${ }^{15}$. Eşler ayrı ayrı veya birlikte dinlendiklerinde, ifadeleri duruşma tutanağına geçirilmelidir ${ }^{16}$.

Nihayet, boşanmanın malî sonuçları ile ergin olmayan çocukların durumu hususunda taraflarca kabul edilecek düzenlemenin (boşanma protokolü/boşanma anlaşması) hâkim tarafından uygun bulunması ile anlaşmalı boşanmaya karar verilebilir. Eşler bu düzenlemeyi yazılı olarak hazırlayıp imzalayarak hâkimin incelemesine sunabilecekleri gibi, anlaşma iradelerini hâkimin huzurunda sözlü olarak da ifade edebilirler, ancak bu olasılıkta irade açıklamalarının duruşma tutanağına geçirilmesi gerekir ${ }^{17}$. Eşlerin yaptıkları anlaşmanın zorunlu içeriğini boşanmanın mali sonuçları ve ergin olmayan çocukların durumu hakkındaki uzlaşma oluşturmaktadır. Eşlerin; maddi ve manevi tazminat, yoksulluk nafakası, çocukların velayetinin kime bırakılacağı ve velayet kendisine bırakılmayan eşin çocuklarla kişisel ilişkisinin nasıl tesis edileceği hususunda anlaşmış olmaları gerekmektedir. Eşlerin mal rejiminin tasfiyesine ya da aile konutuna ilişkin olarak da anlaşmaları mümkündür; fakat bu konular, boşanma anlaşmasının zorunlu içeriğine dâhil olmayıp ihtiyari içeriğini oluşturabilir ${ }^{18}$. Özellikle hâkim, eşlerin yapmış oldukları protokolü uygun bulmazsa bu protokole müdahale ederek, çeşitli değişiklikler yapılmasını önermelidir ${ }^{19}$. Hâkim, uygun gördüğü değişiklikleri eşlere dayatamaz, eşler anlaşmada yapılan değişiklikleri kabul

14 Seçer, s. 262.

15 Dural/Öğüz/Gümüş, N. 653; Özdemir, s. 181; Akıntürk/Ateş, s. 271. İsviçre hukukunda eşlere, boşanma iradelerini bildirmelerinden itibaren iki aylık "düşünme süresi" verilmektedir. Bkz. ZGB Art. 111/II. Bu konuda bkz. Schwenzer/Fankhauser, s. 554-555, N. $27 \mathrm{vd}$.

16 Öztan, s. 694; Dural/Öğüz/Gümüş, N. 653.

17 Schwenzer/Fankhauser, s. 549, N. 9-14; Akıntürk/Ateş, s. 271.

18 Öncü, Özge (2017) “Eşlerin “Anlaşmalı Boşanma” Çerçevesinde Mal Rejiminin Tasfiyesine Yönelik Olarak Yaptıkları Anlaşmalar ve Bu Anlaşmaların Uygulamada Doğurduğu Sorunlar”, Dokuz Eylül Üniversitesi Hukuk Fakültesi Dergisi Prof. Dr. Şeref Ertaş’a Armağan Özel Sayı, C. 19, İzmir, s. 810 vd.

Seçer, s. 273 vd; Dural/Öğüz/Gümüş, N. 655.

19 Özdemir, s. 211; Öztan, s. 695; Dural/Öğüz/Gümüş, N. 656. 
ederlerse boşanmaya karar verebilir ${ }^{20}$. Eşlerin uzlaşamamaları halinde anlaşmalı boşanma talebi reddedilip taraflardan birinin talebi ile davaya çekişmeli usulde devam edilerek TMK m. 166/I ve II uyarınca boşanmaya karar verilebilir² ${ }^{21}$. Yargıtay’a göre eşler, boşanma kararının kesinleşmesine kadar her zaman tek taraflı irade beyanları ile boşanma protokolünden dönebilirler ${ }^{22}$.

\section{BOŞANMA PROTOKOLÜNÜN HUKUKİ NITTELİĞİ}

Anlaşmalı boşanmaya karar verilebilmesinin maddi koşullarından biri olan "anlaşma” unsurunun hukuki niteliği tartışmalıdır. Öğretide ve yargı kararlarında sıklıkla "boşanma protokolü" olarak da adlandırılan bu düzenlemenin hukuki niteliğinin "sözleşme" olduğu kabul edilmektedir" ${ }^{23}$. Fakat bahsi geçen "sözleşme"nin bir usul hukuku sözleşmesi mi, klasik anlamda borçlar hukuku sözleşmesi mi olduğu tartışmalıdır. Boşanma anlaşmasının iki taraflı bir hukuki işlem olduğunu savunan görüşlerden ilkine göre anlaşma, "sulh sözleşmesi" olarak nitelendirilmelidir; zira bu sözleşmenin usul hukuku bakımından özel sonuçları bulunmaktadır ${ }^{24}$. Öğretide savunulan ikinci görüşe göre ise bu durumda eşler arasındaki hukuki işlem, klasik borçlar hukuku sözleşmesidirr ${ }^{25}$. Bu görüş bir adım öteye taşınarak boşanma

20 Özdemir, s. 211; Yılmaz Bilgin, s. 67; Dural/Öğüz/Gümüş, N. 656.

21 Elçin Grassinger, Gülçin (1997) “Boşanma Davasında Eşlerin Boşanmanın Tali Sonuçlarına İlişkin Konularda Anlaşma Yapmaları ve Konu ile İlgili İsviçre Federal Mahkemesi Kararı", İstanbul Üniversitesi Hukuk Fakültesi Mecmuası Prof. Dr. Türkan Rado’ya Armağan Sayısı, C: 55, S: 3, s. 237; Yılmaz Bilgin, s. 68; Öztan, s. 695.

Ayrıca eşlerden birinin anlaşmalı boşanma kararını temyiz etmesinin "anlaşmalı boşanma iradesinden rücu” anlamına geldiği ve davanın çekişmeli boşanma davası olarak görülmesi yönünde bkz. Yargitay 2. Hukuk Dairesi, E: 2016/24006, K: 2018/10507, T: 3.10.2018, metni için bkz. <https://www.lexpera.com.tr/ictihat/yargitay/2-hukuk-dairesi-e-2016-24006-k2018-10507-t-3-10-2018> s.e.t.: 30.07.2019.

Yılmaz Bilgin, s. 72; Seçer, s. 265. Boşanma anlaşmasının hukuki niteliği ile ilgili tartışmalar hakkında bkz. Atmaca Ülkü, Hande (2017) "Türk Hukukunda Anlaşmalı Boşanma Protokolü” (Doktora), Yeditepe Üniversitesi, Sosyal Bilimler Enstitüsü, s. 64 vd. Esener, Turhan (1951) "Boşanmanın Fer'i Neticelerine Dair Mukaveleler”, Ankara Üniversitesi Hukuk Fakültesi Dergisi, C: 8, S: 3, s. 613-614. 
anlaşması “özel onay şartına bağlı özel hukuk sözleşmesi” olarak nitelendirilmektedir ${ }^{26}$. Dördüncü görüşe göre ise boşanma anlaşması belirli bir içeriğe sahip olması ve hâkimin uygun bulması gereken, kendine özgü bir aile hukuku sözleşmesidir ${ }^{27}$. Zira borçlar hukuku sözleşmelerinden farklı olarak boşanma anlaşmasının, hâkim tarafından uygun bulunması ile ortaya çıkan ekonomik sonuçlarının yanı sıra velayet ve eşlerin kişisel durumları bakımından da sonuçları bulunmaktadır. Dolayısıyla klasik anlamda borçlar hukukuna ilişkin ilke ve kurallar, boşanma anlaşmasına "niteliğine uygun düştüğü ölçüde” uygulanmalıdır. Bu nedenle kendine özgü aile hukuku sözleşmesi görüşüne üstünlük tanımak gerekir. Bununla birlikte bu görüşün de tamamlanması gereken bir yönü bulunduğu kanaatindeyiz. Zira boşanma protokolü, eşler arasında karşılıklı ve birbirine uygun iradelerin beyan edilmesi ve hâkimin bu ortak iradeyi uygun bulması ile kendiliğinden sonuç doğurmaz. Bütün bu unsurların mahkemece verilecek kararda açıkça yer alması gerekir. $\mathrm{Bu}$ nedenle kanaatimizce boşanma protokolünün hukuki niteliği çeşitli zaman kesitleri bakımından farklılık taşımaktadır: Boşanma protokolü, hâkim tarafından uygun bulunana kadar kendine özgü bir aile hukuku sözleşmesi; hâkimin bu anlaşmayı uygun bulmasıyla birlikte artık verilen mahkeme kararının içeriğini oluşturması sebebiyle "ilam" olarak nitelendirilmelidir ${ }^{28}$.

Boşanma protokolü bir sözleşme olduğuna göre sözleşmelerin kuruluş ve geçerlilik şartlarına ilişkin kurallar, boşanma protokolü için de geçerlidir ${ }^{29}$. Eşlerin iradelerinin sözleşmenin objektif ve sübjektif esaslı unsurları üzerinde uyuşması gerekir. $\mathrm{Bu}$ anlaşma iradesinin bir boşanma davasında boşanma kararı kesinleşinceye kadar beyan edilebileceği ve anlaşmalı boşanmaya karar

26 Seçer, s. 265; Yılmaz Bilgin, s. 72. Bu görüşe göre boşanma anlaşması şarta bağlı bir sözleşme olup, gerçekleşmesi gereken şart, hâkimin sözleşmeyi uygun bulmasıdır. Atmaca Ülkü, s. 75.

Boşanma protokolünün bu iki yönlü niteliği hakkında açıklamalar için bkz. Schwenzer/Fankhauser, s. 547, N. 3-4.

29 Hâkimin, anlaşmanın ahlâk ve adaba aykırı olup olmadığını, aşırı yararlanma veya irade sakatlığı hallerinin bulunup bulunmadığını araştırması gerektiği yönünde bkz. Öztan, s. 696. 
verilebileceği kabul edilmektedir ${ }^{30}$.Boşanma protokolünün hâkimin onu uygun bulmasıyla birlikte eşler için bağlayıcı hale geldiği göz önünde bulundurulduğunda, kararın kesinleşmesinden önce eşlerin boşanmadan vazgeçtiklerini ancak birlikte bildirmeleri durumunda bu anlaşma sona erdirilmiş olabilirr ${ }^{31}$. Fakat yargı uygulaması aksi yönde gelişmiş olup, eşlerden birinin kararın kesinleşmesinden önceki tek taraflı irade beyanı, boşanma protokolünü sona erdirmeye yetmektedir.

\section{BOŞANMA KARARI VE KARARIN BOŞANMA PROTOKOLÜ İLE İLİ̧Kİsi}

\section{A. GENEL OLARAK}

Boşanma yargılaması sonucunda verilen boşanma kararı, bozucu inşaî (yenilik doğuran) hüküm niteliğindedir ${ }^{32}$. Bu karar ile süregelen evlilik birliği sona ermektedir. Boşanma yargılaması pek çok kez sadece boşanma hükmünden ibaret olmamaktadır. Mahkeme tarafından verilen karar, eşlerin maddi, manevi tazminat ve nafaka talepleri, ortak çocukların velayeti, aile konutunun akıbeti gibi konularda da eda ve tespit hükümleri içerebilir. Bu yönüyle öğretide boşanma hükmü "kombine hüküm” olarak nitelendirilmektedir ${ }^{33}$.

30 Bkz. Yargitay 2. Hukuk Dairesi, E: 2015/5653, K: 2015/19986, T: 3.1112015, karar metninin ilgili kısmı için bkz. Seçer, s. 267, dpn. 47. Eşlerden biri çekişmeli boşanma davasına ilişkin kararı tazminatlar ve nafaka bakımından temyiz etmiş ve temyiz aşamasında anlaşma sağlanmışsa "anlaşma protokolü göz önüne alınıp tazminatlar ve nafakalar konusunda bir karar verilmek üzere hükmün bozulması" yönünde bkz. Yargitay 2. Hukuk Dairesi, E:2013/11504, K: 2014/1737, T: 3.2.2014, karar metni için bkz. $<$ https://www.lexpera.com.tr/ictihat/yargitay/2-hukuk-dairesi-e-2013-11504-k-2014-1737t-3-2-2014> s.e.t: 30.07.2019. Anlaşmalı boşanma bir eşin açtığı davanın diğeri tarafından kabul edilmesi şeklinde gerçekleştiği durumda eşlerden birinin davayı kabul beyanını ancak hüküm verilene kadar geri alabilmesi gerektiği yönünde bkz. Akkaya, s. 250-251.

Öztan, s. 695, Akkaya, s. 251.

Önen, Ergun (1981) İnşaî Dava, Ankara Üniversitesi Hukuk Fakültesi Adalet Yüksek Okulu Yayınları, Ankara, s. 66. 
Her hüküm gibi anlaşmalı boşanma hükmünün de tereddüte yer bırakmayacak biçimde tam, açık ve veciz olması gerekmektedir ${ }^{34}$. Nitekim HMK m. 297'de hükmün kapsamında nelerin bulunması gerektiği açıkça belirtilmiştir. Maddenin 2. fikrasının b bendi uyarınca hükmün sonuç kısmında, gerekçeye ait herhangi bir söz tekrar edilmeksizin, taleplerden her biri hakkında verilen hükümle, taraflara yüklenen borç ve tanınan hakların, sıra numarası altında; açık, şüphe ve tereddüt uyandırmayacak şekilde gösterilmesi gerekir. Bir mahkeme kararının muhatabı sadece davanın tarafları olmayabilir. Tapu sicil müdürlükleri ya da nüfus müdürlükleri gibi kararın icrasıyla görevli merciler bakımından da kararın açık, anlaşılır ve net olması önem taşır ${ }^{35}$. Bu bakımdan koşula bağlı boşanma kararının verilmesinin mümkün olup olmadığı değerlendirilmelidir. $\mathrm{Bu}$ tartışma özellikle boşanma anlaşmasında koşul veya vade kararlaştırıldığı ve bunun da hâkim tarafından uygun bulunarak boşanmaya karar verildiği haller bakımından anlam taşımaktadır.

Öğretide koşula bağlı mahkeme kararı konusu oldukça tartışmalıdır. Fakat ağırlıklı olarak koşula bağlı hüküm verilemeyeceği ileri sürülmektedir ${ }^{36}$. Dolayısıyla boşanma protokolünde yer alan erteleyici veya bozucu koşul içeren ifadelerin hâkim tarafından uygun bulunmayarak hüküm içinde bunlara yer verilmemesi gerektiği kabul edilmelidir. Türk-İsviçre hukukunda koşula ilişkin kuralların niteliği uygun düştügü ölçüde vade için de uygulanmasına bir engel bulunmadığı ileri sürülmektedir ${ }^{37}$. Oysa vade için bu sonuca ulaşmak her zaman kolay olmamaktadır. Zira koşul, gerçekleşmesi objektif olarak şüpheli bir olguyu ifade ederken, vadenin ileride gerçekleşip

34 Boran Güneysu, Nilüfer (2014) Medeni Usul Hukukunda Karar, Adalet Yayınevi, Ankara, s. 228.

35 Boran Güneysu, s. 227.

36 Tanrıver, Süha (1998) "Şarta Bağlı Hüküm Kavramı ve Verilip Verilemeyeceği Sorunu”, Banka ve Ticaret Hukuku Dergisi, C: XIX, S: 4, s. 50, Atalı, Murat (2017) Pekcanitez Usul Medeni Usul Hukuku C. III, 15. Bası, On İki Levha Yayınları, İstanbul, s.1977 vd. Yazar, icraya elverişli olduğu takdirde koşula bağlı hüküm verilebleceğini ileri sürmektedir.

37 Pulaşlı, Hasan (1989) Şarta Bağlı İşlemler ve Hukuki Sonuçları, Dayınlarlı Yayınları, Ankara, s. 71. 
gerçekleşmeyeceği şüpheli değildir ${ }^{38}$. Ancak boşanma protokolündeki ekonomik sonuçlara ilişkin vade içeren yükümlülükler, boşanma protokolünün uygun bulunarak hükümde yer aldığı, hükümde sadece protokole yollama yapılmakla yetinildiği ve protokolün vade içeren yükümlülüklerinin hükümde yer almadığı olasılıklarda farklı hukuki sorunlara sebebiyet vermektedir. Bu sorunlara, protokolün ayni haklara ilişkin yükümlülüklerinin vadeye bağlanması ihtimali bakımından aşağıda ayrıntılı olarak yer verilecektir ${ }^{39}$.

HMK m. 388 gereğince çekişmesiz yargı kararları kural olarak kesin hüküm teşkil etmemekle birlikte yenilik doğuran (inşaî) etki taşıması sebebiyle anlaşmalı boşanma kararının maddi anlamda kesin hüküm niteliğinde olduğu kabul edilmektedir ${ }^{40}$. Hükmün kesinleştiği andan itibaren geleceğe etkili olmak üzere eşlerin hukuki durumunda değişiklik meydana gelir $^{41}$. İnşaî hükmün icrası için icra dairesine başvurmaya gerek bulunmamaktadır; fakat inşaî kararın yanı sıra fer'i sonuçlara ilişkin eda hükümlerine de -boşanmanın sonucu olarak nafaka, maddi ve manevi tazminat alacaklarında olduğu gibi- yer verilmişse ilamlı icra yoluna başvurulabilmesi mümkündür ${ }^{42}$.

Hâkim anlaşmalı boşanmaya ilişkin hüküm verdikten sonra bunun değiştirilmesi mümkün değildir ${ }^{43}$. Bununla birlikte açık yazı, hesap hataları gibi maddi hatalar her zaman düzeltilebilir (HMK m. 204). Fakat hüküm icra edilebilecek açıklıkta değilse yahut uygulanmasında tereddüt yaratacak nitelikteyse, ister kesinleşmiş olsun ister olmasın taraflar hükmün tavzihini talep edebilir ${ }^{44}$. Hükmün tavzihine genellikle icrası aşamasında ihtiyaç

38 Sirmen, Lale (1992) Türk Özel Hukukunda Şart, Banka ve Ticaret Hukuku Araştırma Enstitüsü Yayınları, Ankara, s. 30 ve 87; Pulaşlı, s. 70 vd.

39

40

41

42

43

44 
duyulduğu için, icra edilmesinden sonra tavzihi istenemez ${ }^{45}$. Tavzih ile sadece hükümdeki tereddüt ortadan kaldırılır. Fakat hükümdeki haklar ve borçlar tavzih ile genişletilip daraltılamaz veya değiştirilemez (HMK m. 305/II).

\section{B. PROTOKOLÜN UYGUN BULUNMUŞ, KISA KARARDA YER BULMUŞ VE KARARIN İÇERİĞİ HALİNE GELMIŞ OLMASI}

Anlaşmalı boşanma yargılamasında boşanmanın gerçekleşebilmesi için hâkimin, eşlerin üzerinde uzlaştıkları boşanma protokolünü uygun bulması gerekir. Hâkim tarafından uygun bulunan protokol, anlaşmalı boşanmaya ilişkin mahkeme kararının sonuç kısmında tereddütsüz, açık ve anlaşılır biçimde yer almalıdır ${ }^{46}$.

Anlaşmalı boşanmaya ilişkin mahkeme kararının sonuç kısmında hâkimin anlaşma protokolüne olduğu gibi yer vermeyerek sadece protokole yollama yapmakla yetinmesi, uygulamada sıklıkla karşılaşılan bir durumdur. Hâkimin, boşanma protokolünü uygun bulmuş olmasına rağmen kısa karada protokole yer vermemiş olması ihtimalinde mahkeme kararının icrasının nasıl gerçekleşeceği tartışmalıdır. Öğretide savunulan birinci görüşe göre ${ }^{47}$ hâkim boşanma protokolünü uygun bulmuş, gerekçeli kararda protokol hükümlerine yer vermiş fakat kısa kararda yer vermeyerek sadece yollama yapmakla yetinmişse, bu durumda mahkeme kararının icrasının kabil olması gerekir. Bu görüşe göre hâkimin, protokol hükümlerine kararın sonuç kısmında yer vermeyip sadece kararın gerekçesinde yer vermiş olması durumunda protokol, hükmün bir parçası kabul edilerek kararın icrası mümkün olmalıdır. Konuya ilişkin öğretide savunulan ikinci görüşe ${ }^{48}$ göre ise anlaşmalı boşanma kararının sonuç kısmında protokolün taraflara sağladığı hakların ve yüklediği yükümlülüklerin açık biçimde yer alması gerekir. Bu görüşe göre gerekçeli kararda protokole yollama yapılmakla yetinilmesi, hükmün icra edilebilmesi bakımından yeterli görülmemektedir. Kanaatimizce ikinci görüşe üstünlük

\footnotetext{
45 Atalı, s. 2004.

46 Özdemir, s. 220; Seçer, s. 280.

47 Özdemir, s. 222-223.

48 Seçer, s. 282.
} 
tanınmalıdır. Zira, anlaşmalı olarak boşanmak isteyen eşler boşanma protokolünün içeriği hakkında tam anlamıyla uzlaşmamışlarsa TMK m. 166/III hükmü uyarınca boşanabilmeleri mümkün değildir. Eşler uzlaşmış olsa bile hâkime bu sözleşmeye gerektiğinde müdahale etme görevi verilmiş, gerekli değişiklikleri önermesi üzerine eşler bu değişiklikler üzerinde de anlaşırlarsa protokolü uygun bularak boşanma kararı vermesi belirtilmiştir. Tarafların iradelerinin bu kadar önemli olduğu bir yargılama faaliyetinde, bu iradenin mahkemenin vereceği kararın sonuç kısmında açıça yer almamasının sebebini anlamak mümkün değildir. Hâkim tarafindan uygun bulunan taraf iradelerinin hükmün sonuç kısmında açıkça, tereddüte yer bırakmayacak biçimde yer alabilmesi hem bu hükmün sonuçlarından doğrudan etkilenenler, hem de karar gereğince işlem yapması gerekecek merciler (nüfus müdürlükleri, tapu sicil müdürlükleri gibi) bakımından önem arz etmektedir. Örneğin, mahkeme kararı gereğince işlem yapması gereken tapu sicil müdürlüklerindeki görevlilerin, gerekçeli kararı incelemesi yahut gerekçeli kararı yorumlayarak yapacağı işlemi tayin etmesi beklenemez. $\mathrm{Bu}$ ihtimallerde pek çok yeni hukuki sorunun ve doğması muhtemel hak kayıpları yaşanmasının önüne geçmek adına, boşanma protokolünün hâkim tarafından uygun bulunduğunun ve taraflara tanınan haklar ile yüklenen yükümlülüklerin neler olduğunun açıkça, teker teker ve anlaşılır biçimde kısa kararda ve gerekçeli kararın sonuç kısmında yer alması gerektiği kabul edilmelidir.

Yargıtay Hukuk Genel Kurulu'nun bir kararına konu olan olayda eşler bir protokol imzalamış, bunu mahkeme önünde de beyan ederek boşanmış ancak bu protokol ne kısa kararın içeriğinde yer almış ne de kararda protokole yollama yapılıp kararın eki haline gelmiştir. Kararda protokolün yok hükmünde olduğu ifade edilmektedir ${ }^{49}$. Üstelik, bahsi geçen olayda eşler

49 Bkz. “...İzmir 9. Aile Mahkemesinde görülen boşanma davası sırasında, taraflar 14.06.2007 günlü protokolü sunmuşlar ve 14.06.2007 günlü celsede de imzalı beyanları ile protokolün doğruluğunu kabul ettiklerini belirtmişlerse de, hakim tarafından boşanma ilamının hüküm fikrasında protokol tasdik edilmediği gibi, A..

Ç..tarafından protokole hüküm fikrasında yer verilerek hüküm fikrasının düzeltilmesine ilişkin tavzih istemi de mahkemece 17.04.2008 tarihinde reddedilmiş, karar Yargitay 2. Hukuk Dairesince 18.06.2009 tarihinde onanarak kesinleşmiştir. 
protokolü imzalamış, mahkemeye duruşma sırasında ibraz etmiş, fakat her nasılsa boşanma hükmünde protokolün uygun bulunduğu ifadesi dahi yer almamış olmasına rağmen anlaşmalı boşanmaya karar verilmiş, daha sonra davalı A.'nın tavzih yoluyla protokolün hükme ilave edilmesi talebi de reddedilmiştir. Dava konusu olayın ilerleyen safhalarında yaşanan hak kayıpları bundan sonra başlamıştır. Anlaşmalı boşanmaya karar veren hâkimin, boşanma protokolüne hükümde yer vermemesinin sebebi, Hukuk Genel Kurulu kararından anlaşılamamaktadır. Dolayısıyla anlaşmalı boşanmanın en önemli unsuru olan "anlaşma"nın nasıl sağlandığı da açık değildir. Anlaşma sağlanmamışsa TMK m. 166/III’teki açık hükme rağmen hangi hukuki gerekçe ile boşanma kararı verildiği de anlaşılamamaktadır. Kanaatimizce böyle bir durumda yaşanan hak kayıplarından ötürü hâkimin hukuki sorumluluğunu düzenleyen HMK m. 46/I-c bendi uyarınca devletin sorumluluğu gündeme gelmelidir. Zira TMK m. 166/III hükmü hangi koşullar bir araya geldiğinde anlaşmalı boşanma kararının verilebileceğini açıkça

Bilindiği üzere TMK’nın 166/3.maddesinde düzenlenen boşanma davalarında yapılan protokollerin geçerliliği hakimin protokolü uygun bularak tasdikine bağlıdır. Tasdik edilmeyen ve böylece boşanma kararının eki haline getirilmeyen protokol ise yok hükmündedir.

Somut olayda, taraflar arasında her ne kadar 14.06.2007 tarihinde bir protokol yapılmışsa da, boşanma ilamının eki olmayan ancak tarafların kabulünde bulunan protokole konu 4 parsel sayılı taşınmazdaki 2 ve 5 nolu bağımsız bölümlerin 2004 yılında satın alındığı, davalı koca adına tapu kayıtlarının oluştuğu, 2008 yılında yargılama sırasında da üçüncü kişilere satış suretiyle temlik edildiği; 35 DID 29 plaka nolu aracın da 2005 yılında satın alınıp 2008 yılında üçüncü kişiye satıldığı anlaşılmakla, söz konusu malların evlilik birliği devam ederken satın alındığı ve boşanma kararının kesinleşmesinden sonra elden çıkarıldığı, böylece protokolün infaz kabiliyetinin kalmadığı anlaşıldığına göre, mahkemece TMK’nın 202. maddesi uyarınca taraflar arasında edinilmiş mallara katılma rejiminin geçerli olduğu kabul edilmek suretiyle, iddia ve savunma doğrultusunda taraf delilleri toplanarak, gerektiğinde bilirkişi incelemesi yaptırılarak hasıl olacak sonuca göre karar verilmesi gereğine değinen bozma ilamı yerindedir.

Hukuk Genel Kurulu görüşmeleri sırasında bir kısım üyeler tarafından, taraflar TMK’nın 166/3.maddesiuyarınca anlaşmalı olarak boşandıklarına göre, protokolün geçerliliği için ayrıca hüküm fikrasında yer almasına gerek olmadığından yerel mahkeme kararının onanması gerektiği ileri sürülmüşse de bu görüş Kurul çoğunluğu tarafından benimsenmemiştir...”. Yargitay Hukuk Genel Kurulu, E:2013/1542, K: 2015/1110,T: 27.03.2015, karar metni için bkz. <https://www.lexpera.com.tr> s.e.t: 23.09.2019. 
belirtmektedir. Tarafların üzerinde anlaştığı bir boşanma anlaşması yoksa, TMK m. 166/III'e göre karar verilemez; varsa da anlaşmalı boşanmanın koşullarının gerçekleştiği ve hangi konularda nasıl anlaşılarak boşanma kararına hükmedildiğinin mahkeme kararından açıkça anlaşılması gerekir. Hâkimin, uygun bulmayıp kararda yer vermediği bir protokole dayanarak hüküm tesis etmesi halinde TMK m. 166/III'teki açık hükme aykırı karar verilmiş olur. $\mathrm{Bu}$ da sorumluluğunun doğmasına sebep teşkil eder. $\mathrm{Bu}$ istenmeyen sonuca mahal vermemek için, hâkim tarafından uygun bulunan boşanma anlaşmasının kısa kararda icra edilebilir, açık ve anlaşılır biçimde yer alması son derece önemlidir.

\section{BOŞANMA KARARININ KESINLEŞMESI}

Anlaşmalı boşanma yukarıda belirtildiği üzere bir çekişmesiz yargı işi olarak kabul edilir. Bununla birlikte ilk derece mahkemesinin boşanma kararı vermesiyle hükmün inşaî etkisi ortaya çıkar, hükmün şekli anlamda kesinleşmesi ile birlikte artık hüküm bağlayıcı bir hal alır ${ }^{50}$. HMK m. 387 uyarınca ilk derece mahkemesinin kararına karşı istinaf yoluna başvurulabilir ${ }^{51}$. Çekişmesiz yargı işi olarak kabul edilen anlaşmalı boşanma kararına ilişkin bölge adliye mahkemelerinin istinaf incelemesi sonucunda verdiği karara karşı temyiz yoluna başvurulamaması gerektiği sonucuna ulaşılabilir. Fakat yargı uygulaması aksi yönde gelişmiş olup anlaşmalı boşanma davalarında çekişmeli boşanma davaları için uygulanan usul benimsenmektedir ${ }^{52}$.

Boşanma anlaşmasının zorunlu içeriğini oluşturması gereken boşanmanın mali sonuçları ve ergin olmayan çocukların durumuna ilişkin herhangi bir protokol hükmü bulunmamasına rağmen hâkim eşlerin anlaşmalı olarak boşanmasına karar vermişse, eşlerin daha sonra bu konulara

\footnotetext{
50 Akkaya, s. 259.

51 Bkz. Akkaya, s. 259.

52

Bkz. Yargitay 2. Hukuk Dairesi, E: 2015/23806, K:2015/22491, T: 23.11.2015; Yargitay 2. Hukuk Dairesi, E: 2017/4360, K: 2018/12814, T: 12.11.2018, İstanbul Bölge Adliye Mahkemesi 10. Hukuk Dairesi, E: 2017/71, K: 2017/140, T: 15.2.2017, karar metni için bkz. <https://www.lexpera.com.tr> s.e.t: 13.05.2020.
} 
ilişkin taleplerini dava edip edemeyecekleri hususu tartışmalıdır. Eşlerin protokolde yoksulluk nafakasına veya maddi ve manevi tazminata ilişkin herhangi bir hükme yer vermeyip boşanma kararı kesinleştikten sonra bu taleplere ilişkin dava açmaları halinde boşanma hükmünün bu konularda kesin hüküm oluşturduğu kabul edilmektedir ${ }^{53}$. Fakat çocuğun velayetine, çocukla kişisel ilişki kurulmasına ve iştirak nafakasına ilişkin olarak aynı sonuca ulaşılmamakta; bu konularda daha sonra dava açılabileceği kabul edilmektedir ${ }^{54}$. Öğretide savunulan ikinci görüşe göre ise anlaşmalı boşanma protokolünün ve dolayısıyla boşanma hükmünün zorunlu içeriğini oluşturması gerekmesine rağmen maddi tazminat ile yoksulluk nafakasına değinmeden boşanma kararı verilmiş ise, karar kesinleştikten sonra bu konular yeni bir davanın konusu olabilmelidir ${ }^{55}$.

Kanaatimizce ortak çocuğun velayeti ve çocukla kişisel ilişki kurulması konularında mahkemelerin re'sen araştırma, önlem alma, harekete geçme yetkileri bulunduğu için, bu iki konuda anlaşılmış ve bu anlaşma hâkim tarafından uygun bulunmuş olsa bile, bu konuların boşanmanın fer'i sonuçlarından ve iştirak nafakasından ayrı değerlendirilmesi gerekir. Bu iki konu bakımından, her zaman çocuğun üstün yararına göre değişiklik yapılabilmesi mümkün olduğu için (TMK m. 182-183), hâkim tarafından uygun bulunan boşanma protokolü, maddi anlamda kesin hüküm teşkil etmez. Boşanmanın mali sonuçları, ortak çocukların velayeti ve çocuklarla kişisel ilişki kurulması konuları boşanma anlaşmasının zorunlu unsuru olmasına rağmen bu konuya ilişkin açık bir anlaşma hükmü içermeyen bir boşanma kararı verilmiş ve bu karar kesinleşmişse, daha sonra bu konuların her biri dava konusu olabilmelidir. Zira boşanma kararı veren hâkimin bu hususlar bakımından eksiklik barındıran bir karar vermiş olmasının dezavantajlı hukuki sonuçlarına taraflar katlanmamalıdır. Hâkimin bu

53 Öğretide Arbek, anlaşmalı boşanma hükmünde yoksulluk nafakasına ilişkin herhangi bir ifadenin yer almamasının, tarafların boşanma sonucunda yoksulluğa düşmediği anlamına geldiğini, dolayısıyla boşanma kararının bu konuya ilişkin kesin hüküm teşkil ettiğini belirtmektedir. Bkz. Arbek, Ömer (2005) "Boşanmanın Mali Sonuçları”, Ankara Üniversitesi Hukuk Fakültesi Dergisi, C: 54, S: 1, s. 145.

Öztan, s. 697. 
yargılama faaliyetini özenli biçimde gerçekleştirmesi ve TMK m. 166/III hükmündeki konulara ilişkin açık, anlaşılır bir hüküm tesis etmesi gerekirdi. Zira bu konular, hâkimin incelemesi gereken konular olarak değerlendirilip, söz konusu incelemenin gerçekleşmemesi, taraflar bakımından bir hak kaybına neden olmamalıdır. Ancak Yargıtay uygulaması aksi yönde gelişmiş olup, boşanma hükmünde boşanmanın fer’i sonuçlarına ilişkin ilişkin hüküm bulunmaması bu konuya ilişkin kesin hüküm olarak nitelendirilmektedir ${ }^{56}$.

\section{TAŞINMAZLAR ÜZERINNDEKI AYNI HAKLARA İLIŞKİN PROTOKOL HÜKÜMLERİ VE BU HÜKÜMLERİN İCRASI}

\section{A. GENEL OLARAK}

Boşanma protokolünün zorunlu içeriğine dâhil olmasa bile, ülkemizde, taşınmazlara ilişkin ayni hakların anlaşmalı boşanma aşamasında özel bir önem taşıdığı sosyal bir gerçektir. Özellikle aile konutunun mülkiyeti boşanmak isteyen eşlerden birine, ortak çocuk ya da çocuklara devredilmek istenebilmektedir. Zaman zaman eşlerin, boşanmanın ekonomik sonuçlarına ilişkin olası bir uyuşmazlığı bertaraf etmek için boşanma protokollerinde taşınmaz mülkiyetinin devrine ya da taşınmaz üzerinde sınırlı ayni hak kurulmasına ilişkin hükümlere yer verdikleri görülmektedir. Benzer şekilde, mal rejiminin tasfiyesi ya da maddi ve manevi tazminat talepleri nedeniyle nakit ödeme gücü bulunmayan eşlerin taşınmaz üzerindeki ayni hakları boşanma protokollerine konu ettikleri bilinmektedir. İşte bu gibi sebeplerle boşanma protokolünde yer alan taşınmazlar üzerindeki ayni haklara ilişkin hükümler, birçok hukuki sorunu beraberinde getirebilmektedir.

56 Bkz. “...anlaşmalı boşanma davalarında eşler boşanma ve boşanmanın ferileri konusunda anlaşmış oldukları gibi, birbirlerine herhangi bir kusur izafesinde bulunmadıklarından başka bir ifadeyle bu davalarda yeniden kusur araştırması yapılması mümkün olmadığından mahkemenin eldeki davada topladığı delillere göre belirlediği davalının kusurlu davranışlarının hükme esas alınması ve davacı yararına maddi ve manevi tazminata hükmedilmesi doğru görülmemiştir. Bu durumda yerel mahkemenin direnme gerekçesi Özel Daire bozma kararında ve yukarıda belirtilen bu ilâve gerekçe dikkate alındığında usul ve yasaya aykırıdır.”. Yargıtay Hukuk Genel Kurulu, E:2017/3067, K: 2019/512, T: 02.05.2019, karar metni için bkz. <https://karararama.yargitay.gov.tr /YargitayBilgiBankasiIstemciWeb/pf/sorgula.xhtml $>$, s.e.t:04.02.2020. 
Bilindiği gibi boşanma anlaşmasının geçerliliği, herhangi bir şekil şartına tâbi değildir. Bu anlaşmalarda taşınmaz mülkiyetinin devrine veya taşınmaz üzerinde sınırlı ayni hak kurulmasına ilişkin irade beyanları yer alabilir. TMK m. 706 ve 2644 sayılı Tapu Kanunu m. 26 uyarınca taşınmaz mülkiyetini devir borcu doğuran sözleşmelerin geçerli biçimde sonuç doğurabilmesi için resmi şekilde yapılmaları gerekmektedir ${ }^{57}$. Fakat hâkimin boşanma protokolünü uygun bularak protokolün kararın icra edilebilir nitelikteki içeriği haline gelmesiyle birlikte, artık boşanma anlaşmasının ne şekilde yapılmış olduğunun önemi kalmaz. Bu nedenle tapuda gerçekleştirilen tescil, mahkeme kararı gereği gerçekleşen açıklayıcı tescil işlemi olarak nitelendirilmelidir. Kısaca özetlenen bu süreçte, bu çalışma bakımından önem taşıyan husus, boşanma anlaşmasının şeklinden çok, bu iradelerin mahkemenin kararının içeriği haline ne şekilde gelmiş olduğudur. Ayrıca, boşanma anlaşması ile taşınmazın mülkiyetini kazanacak veya lehine bir sınırlı ayni hak kurulacak kişinin boşanmak isteyen eşlerden biri veya üçüncü kişi yahut kişiler olması durumunda, anlaşmalı boşanma hükmünün icrası hukuki açıdan özellik arz etmektedir. Aşağıda, bahsi geçen bu olasılıklar bakımından boşanma karalarının icrasına ilişkin sorunlar incelenmektedir.

\section{B. KAZANDIRMANIN EŞLERDEN BİRI LEHINNE YAPILMASI HALINDE}

\section{Ayni Hakkın Geçtiği An ve Tescil İşleminin Hukuki Niteliği}

Eşlerden birinin sahip olduğu mülkiyet hakkını devretmesine veya diğer eş lehine sınırlı ayni hak kurulmasına ilişkin kayıtlar boşanma protokolünde yer alabilir. Eşlerin bu hallerde güttüğü amaç; maddi veya manevi tazminat ve yoksulluk nafakasına ilişkin borçlarını ödemek veya ödenecek meblağı azaltmak, yahut mal rejiminin tasfiyesi sonucunda ödenecek katılma alacağının ifası, aile konutu ile ev eşyasının paylaşılması vb. konularda doğabilecek uyuşmazlıklara ilişkin nihai bir çözüm getirmek olabilir. Boşanmak isteyen eşlerden biri tarafından ayni hakkın kazanılabilmesi için bu

57 Taşınmaz üzerinde diğer sınırlı ayni hakların kazanılmasında mülkiyete ilişkin hükümlerin uygulanacağı hakkında bkz. TMK m. 780, 795, 840, 856. 
yöndeki irade açılamalarına boşanma protokolünde yer verildiği görülmektedir. Konuya ilişkin hukuki sorunlar da bu aşamadan itibaren baş göstermektedir.

Anlaşmalı boşanmak isteyen eşler, anlaşma müzakereleri sırasında birine ait olan bir taşınmazın mülkiyetini diğerine devretmiş yahut bir sınırlı ayni hak kurmuş ve sonrasında anlaşma sağlanarak boşanma gerçekleşmişse, boşanma protokolü ve kısa kararın içeriği haline gelmiş protokol hükümlerinin icrası, bu açıdan hukuki bir sorun teşkil etmemektedir. Zira ayni hakkın devri, mahkeme kararından önce gerçekleşmiş demektir. Fakat, bir taşınmaz üzerinde eşlerden birine ait olan mülkiyet hakkının devri veya sınırlı ayni hakkın kurulması daha önceki bir aşamada değil de boşanma anlaşması ile kararlaştırılmışsa, bu durumda anlaşmanın kısa kararın (hüküm fikrasının) içeriği haline gelmiş olup olmaması, yargı uygulamasında hukuki sürecin devamı bakımından belirleyici rol oynamaktadır:

Tapuya kayıtlı bir taşınmazın mülkiyetinin diğer eşe devri veya diğer eş lehine sınırlı ayni hak kurulması konusunda uzlaşılmış, yazılı anlaşma veya sözlü olarak gerçekleşip tutanağa geçirilmiş irade beyanları açık, anlaşılır, icra edilebilir bir kısa karar halini almışsa, ayni hak, kararın kesinleşmesiyle diğer eş tarafından tescilsiz olarak kazanılmış olur ${ }^{58}$. Zira artık bu "anlaşma”, "ilam" haline gelmiştir. TMK m. 705/II uyarınca mahkeme kararı, taşınmaz mülkiyetinin tescilsiz kazanıldığı hallerden biridir. Boşanma kararının şekli anlamda kesinleşmesi ile birlikte inşaî etki ortaya çıar ve ayni hak kazanımı gerçekleşir $^{59}$. Bu olasılıkta, ayni hakkı kazanan kişi, doğrudan doğruya tescil işlemini yaptırabilir (TMK m. 716/II, TMK m. 1013/III). Boşanma kararını veren mahkemenin, ilamı evrak-1 müsbite olarak ilgili tapu sicil müdürlüğüne

58 Oğuzman, M. Kemal /Seliçi, Özer/Oktay-Özdemir, Saibe (2017) Eşya Hukuku, 20. Baskı, Filiz Kitabevi, İstanbul, N. 1505; Özdemir, s. $180 \mathrm{vd.}$

59

Bkz. Eren, Fikret (2016) Mülkiyet Hukuku, Gözden Geçirilmiş 4. Baskı, Yetkin Yayınları, Ankara, (Eren, 2016) s. 252-253; Akkaya, s. 258-259. Mülkiyet hakkının mahkeme kararı ile tescilden önce kazanılabilmesi için inşai bir kararın gerekli olduğu yönünde bkz. Oğuzman/Seliçi/Özdemir, N. 1500. 
göndermesi ve tapu müdürlüğünün tescil işlemini re'sen yapması gerekmektedir (İ̈K m. 28) ${ }^{60}$.

Anlaşmalı boşanmaya ilişkin mahkeme kararında eşlerden birine ait taşınmaz üzerindeki mülkiyetin diğer eşe devri veya eşlerden biri lehine sınırlı ayni hak kurulmasına ilişkin irade beyanının yer aldığı boşanma protokolünün kısa kararda yer almayıp, protokole sadece kararın ekinde yer verilmesi, hatta ekinde dahi yer verilmemesi uygulamada sık rastlanan durumlardır. İlk olasılıkta protokol, kararın ekinde yer almakta, fakat kısa kararda doğrudan doğruya ve açıkça yer almamaktadır. Bu durumda öğretide savunulan bir görüşe göre ${ }^{61}$ kısa kararda "protokolün aynen tasdikine" ilişkin bir ifade yer alıyorsa protokol hüküm ve sonuç doğurmaktadır. Bu ifade yer almasa bile protokol hükümleri kısa kararda zikredilmişse, bu görüşe göre yine protokol hüküm ve sonuç doğurmaktadır" . Kisa kararda "protokolün aynen tasdikine" ifadesi yer almamasına rağmen kararın ekinde protokol hükümlerine yer verildiği hallerde de artık boşanma kararının ve dolayısıyla protokol hükümlerinin icra edilebilir nitelikte olduğu ileri sürülmektedir ${ }^{63}$. Fakat hem bu olasılıkta hem de kararın ekinde dahi kısa kararda uygun bulunduğu belirtilen protokol hükümlerine yer verilmemişse kanaatimizce bu durumda hüküm icra edilebilir açıklıkta olmadığı için, hükmün tavzihine ihtiyaç duyulacaktır. Yargıtay'ın protokolün kısa kararda yer almaması

60 Aynı yönde bkz. Yargıtay İçtihadı Birleştirme Kararı, E:1949/13, K: 1951/5 T: 20.06.1951, karar metni için bkz. <http://www.resmigazete.gov.tr/arsiv/7950.pdf> s.e.t: 20.09.2019.

61 Atmaca Ülkü, s. 178. Aynı yönde bkz. Yargitay 12. Hukuk Dairesi, E: 2012/4709, K: 2012/20013, T: 11.6.2012. Karar uyarınca "Boşanmanın eki niteliğindeki sözleşmeler, boşanma davası süreci içinde yapılmak koşuluyla hakimin onayı ve davanın boşanmayla sona ermesi ile geçerlilik kazanır. Dayanak ilamın hüküm fikrasında, yukarıda değinilen şekilde taraflar arasındaki anlaşmadan bahsedildiği gibi, hükmün gerekçesinde de tarafların anlaşmasının mahkemece de uygun bulunduğu belirtildiğinden ve dolayısıyla protokolün dayanak boşanma ilamının eki olup, koşullarına aynen uyulması gerektiğinden takibe konu edilebileceği düşünülmeksizin, borçlunun borca itirazlarının esası hakkında bir karar vermek gerekirken yazılı gerekçe ile takibin iptaline dair hüküm tesisi isabetsizdir.”. Kararın tam metni için bkz. <https://www.lexpera.com.tr/ictihat/yargitay/12-hukuk-dairesi-e-20124709-k-2012-20013-t-11-6-2012> s.e.t: 02.10.2019.

62 Özdemir, s. 222.

63 Özdemir, s. 222. 
durumunda icra edilmesinin mümkün olmadığı yönünde kararı mevcuttur ${ }^{64}$. Eşler bir protokol imzalamış, bunu mahkeme önünde de beyan ederek boşanmış ancak bu protokol ne kısa kararın içeriğinde yer almış ne de kararda protokole yollama yapılmış ise bu durumda, Yargıtay Hukuk Genel Kurulu kararı uyarınca protokolün yok hükmünde nitelendirildiği belirtilmişti ${ }^{65}$. Yüksek Mahkeme'nin bahsi geçen kararında yer alan "Bilindiği üzere TMK'nın 166/3.maddesinde düzenlenen boşanma davalarında yapılan protokollerin geçerliliği hâkimin protokolü uygun bularak tasdikine bağlıdır. Tasdik edilmeyen ve böylece boşanma kararının eki haline getirilmeyen protokol ise yok hükmündedir." ifadelerine katılmaya imkân bulunmamaktadır. "Yokluk", bir hukuki işlemin kurucu unsurları olan karşlıklı ve birbirine uygun irade beyanlarının bulunmaması anlamına gelir ${ }^{66}$. Hâlbuki tarafların hazırladığı boşanma protokolü, hukuki işlemin sahip olması gereken kurucu unsurlara sahiptir. Fakat bu irade beyanları, hakim tarafından uygun bulunarak hükmün içeriğini oluşturmadığı için istenen hukuki sonuçları doğurabilecek nitelikte değildir. İrade beyanlarının istenen hukuki sonuçları meydana getirememesi durumunda ise yokluk değil,

64 Bkz. Yargitay 12. Hukuk Dairesi, E: 2018/7872, K: 2019/9801, T: 10.6.2019. Karar uyarınca "Hukuk Genel Kurulunun 08/10/1997 tarih ve 1997/12-517 E.-1997/776 K. sayılı kararında da vurgulandığı üzere 'ilamların infaz edilecek kısmı hüküm bölümüdür. Diğer bir anlatımla, hükmün içeriğinin aynen infazı zorunludur. $O$ nedenle sınırlı yetkili icra mahkemesince ilamın infaz edilecek kısmı yorum yoluyla belirlenemez.'

Somut olayda; takibe dayanak yapılan ilam, anlaşmalı boşanma protokolünün onaylanması niteliğinde olup, kurulan hüküm eda niteliğinde değildir. Her ne kadar dayanak ilama esas alınan protokolde; 1.000.000 TL tazminat bedelinin ödeneceği yazılı ise de protokole ilişkin bu kısım mahkemece verilmiş ve ödemeye ilişkin bir karar değildir. Mahkemece bir işin yapılmasına ilişkin olmak üzere verilen eda hükmü içeren kararlar ilamlı icraya konu edilebilir. Takibe dayanak ilam, anlaşmalı boşanma protokolünün onaylanması mahiyetinde olup, ilamlı icra takibine konu edilemeyeceği anlaşılmaktadır.”. Kararın tam metni için bkz. <https://www.lexpera.com.tr/ictihat/yargitay/12-hukuk-dairesi-e-20187872-k-2019-9801-t-10-6-2019> s.e.t: 02.10.2019.

Bkz. dpn. 49'daki karar. Yargitay Hukuk Genel Kurulu, E:2013/1542, K: 2015/1110,T: 27.03.2015, karar metni için bkz. <https://www.lexpera.com.tr> s.e.t: 23.09.2019.

Edis, Seyfullah (1987) Medeni Hukuka Giriş ve Başlangıç Hükümleri, gözden geçirilmiş 3. Bası, Ankara Üniversitesi Hukuk Fakültesi Yayınları, Ankara, s. 161; Oğuzman, M. Kemal/ Öz, Turgut (2019) Borçlar Hukuku Genel Hükümler C. I, Vedat Kitapçılık, İstanbul, s. 182. 
geçersizlik (hükümsüzlük) söz konusu olur" ${ }^{67}$ Yüksek Mahkeme'nin “tasdik edilmeyen, böylece boşanma kararının eki haline getirilmeyen protokol” bakımından yaptığı “yokluk” nitelendirmesi yerine, gerekiyorsa geçersizlik türlerine ilişkin bir değerlendirme ve hukuki nitelendirme yapması isabetli olurdu. Eşlerin bir konuya ilişkin aynı yönde, üstelik mahkeme huzurunda beyan ettikleri iradeleri, kararın eki haline gelmediği için yok sayılmayıp, bunun yerine umulan hukuki sonucu meydana getirmeye elverişli olmayan bu irade beyanlarının geçerliliği veya geçersizliğinin tartışılması, hukuki sorunun çözümüne de katkı sağlayabilirdi.

Tapu sicil müdürlüklerince de kısa kararda yer almayan, ancak kararın eki haline gelmiş olan ve taşınmaz üzerinde sınırlı ayni hak kurulmasını veya mülkiyetin devrini içeren protokol hükümlerinin gereği olarak tescil işlemi yapmaktan imtina edilmektedir. Bir diğer ifadeyle, tapu sicil müdürlükleri tarafından ister kısa karada sadece yollama yapılmış olsun, ister kısa kararda hiç yer verilmemiş olsun fark gözetilmeksizin, ayni hak kurulmasına veya devrine ilişkin protokol hükümleri gereğince tescil işlemi yapılmamaktadır. Hatta mahkeme kararlarının infazı hakkında hukuki görüş istenmesi sebebiyle Çevre ve Şehircilik Bakanlığı Tapu ve Kadastro Genel Müdürlüğü Hukuk Müşavirliği tarafından yapılan değerlendirmeye göre ${ }^{68} \mathrm{kısa}$ kararda "tescil” ifadesi yer almadıkça tapu sicil müdürlükleri boşanma kararı uyarınca tescil işlemi yapmamalıdır. İlgili müşavirlikten görüş istenen olayda anlaşmalı boşanma protokolünde "Taraflar karşılıklı olarak birbirinden gerek bu davada ve gerekse bundan sonra nafaka ve tazminat talep etmeyecekler, buna karşılık Zafer D.'nin maliki olduğu halen davalı ...'in ikamet ettiği ... Mah. 73 pafta, 7338 ada, 1 parselde bulunan 202/42 Sk. No: 4 D: 19 Buca/İzmir adresindeki mesken vasıflı taşınmaz ... adına tapuda devir yapılacaktır... "ifadesi yer almaktadır. Boşanma kararının hüküm kısmında da "taraflar arasında düzenlenen 16/12/2004 tarihli protokolün aynen onanmasina...” ifadesine açıkça yer verilmektedir. Malik eski eşin tapuda devre yanaşmaması üzerine

67 Edis, s. 161. Geçersizlik türleri hakkında ayrıntılı açıklamalar için bkz. Oğuzman/Öz, (2019), s. $182 \mathrm{vd}$.

68 B.09.1.TKG.061-647-03-01-10-210/künyeli görüş yazısının tam metni için bkz. $<$ https://www.tkgm.gov.tr/tr/icerik/tapu>, s.e.t: 23.09.2019. 
diğer eş, ilgili tapu sicil müdürlüğünden kesinleşmiş boşanma kararı gereğince lehine tescil yapılmasını talep etmiş ve talebi reddedilmiştir. Reddin gerekçesi şu ifadelerle belirtilmektedir: "Karar incelendiğinde, söz konusu taşınmazın mülkiyetinin devri konusunda malik davacıya yükümlülük getirilmiştir. Taraflar devir konusunda anlaşmış ve bu yönde karar verilmiştir. Ancak karar tescil hükmünü içermediğinden ve devre yönelik talep hakkını taraflara yüklediğinden malikin kendi rızası ile Tapu Sicil Müdürlüğünde resmi senet düzenlenmek sureti ile devir teslim yapması, bunun sağlanamaması durumunda boşanma davasının hükmüne göre tescil talebinde bulunanın tapu iptal ve tescil davası açması ve tescil hükmünü içeren kesin yargı kararına göre işlem yapılması gerekmektedir.” ifadeleriyle talepte bulunan kişiye ikinci bir dava açma yükümlülüğü getirilmektedir. Bu ikinci davanın ise "tapu iptal ve tescil davası" olduğuna işaret edilmektedir.

Çevre ve Şehircilik Bakanlığı Tapu ve Kadastro Genel Müdürlügü Hukuk Müşavirliği'nin yukarıda belirtilen hukuki görüşü birçok açıdan eleştiriye açıktır. İlk olarak, bilindiği gibi tapuya kayıtlı taşınmazlar üzerindeki ayni hakların "devredilmesi” ile kast edilen, sicilde hak sahibi görünen kişinin, sahip olduğu bu hakkı devretmesidir. Zira tapu sicilinde hak sahibi olarak görünmek, eşya üzerinde fiili hâkimiyete de işaret eder ve buna "sicil zilyetliğì" denir ${ }^{69}$. Dolayısıyla "devir"in öncelikle, bir eşyanın zilyetliğinin devrini ifade edebileceği düşünülse bile, bahsi geçen protokolde “... 'nın makliki olduğu taşınmaz ... tapuda devir yapılacaktır." ifadesi, tereddüte mahal bırakmayacak biçimde zilyetliğin değil, ayni hakkın devrini işaret etmektedir. Kaldı ki söz konusu taşınmazda fiilen oturan kişi, yani dolaysız zilyet de lehine tescil talep eden davacıdır. Ayrıca, hukuki görüşün daha da çelişkili olan yönü, davacının uygulamadaki yanlış adıyla "tapu iptal ve tescil davası” açması gerektiğinin belirtilmesidir ${ }^{70}$. Ne yazık ki ülkemizde, TMK m.

69 Ünal, Mehmet/Başpınar, Veysel (2017) Şeklî Eşya Hukuku, Güncellenmiş ve Genişletilmiş 9. Baskı, Savaş Yayınevi, Ankara, s. 112-113.

70 Türk Medeni Kanunu'nda taşınmazın aynına yönelik davalardaki terminoloji sorunu ile ilgili olarak bkz. Özmen, Etem Saba/Aydın, Gülşah Sinem(2014) “Tapu İptal Davası Olarak Yanlış Adlandırma İle Açılan Davalar (Tescili İsteme Davası/ Yolsuz Tescilin Düzeltilmesi Davası", İstanbul Barosu Dergisi, C: 88, S: 6, s. 179 vd. 
1025'e dayanan tapu sicilinin düzeltilmesi davası da, TMK m. 716'ya dayanan tescile zorlama davası da "tapu iptal ve tescil davası" olarak adlandırılmakta ve bu davalar arasındaki son derece büyük farklılıklar göz ardı edilmektedir. Bahsi geçen hukuki görüşte kast edilen dava, hukuki dayanağı TMK m. 1025 olan ve öğretide "tapu sicilinin düzeltilmesi davası" olarak adlandırılan dava ise, bu dava tapudaki "yolsuz tescil"in, yani gerçek hak durumunu yansıtmayan tescilin düzeltilmesi amacıyla açılır ${ }^{71}$. Bu bilginin somut olaya uygulanması neticesinde ulaşılması gereken sonuç şudur: Davacının malike karşı tapu sicilinin düzeltilmesi davası açması gerektiği tavsiye ediliyorsa, tapuda malik adına var olan kaydın yolsuz olduğu, bir diğer ifadeyle gerçek hak durumunu yansıtmadığı zımnen kabul edilmiş demektir. Bunun anlamı da maddi hukuk bakımından ayni hakkın tescil talebinden önceki bir aşamada, yani tescilsiz kazanma hallerinden biri olan mahkeme kararının şekli anlamda kesinleşmesiyle kaybedildiği, dolayısıyla artık lehine kazandırma yapılan eşin tapuya kayıtlı taşınmaz üzerindeki ayni hakkı tescilsiz olarak kazanmış olduğudur. Tapu sicilinin düzeltilmesi davası sonucunda gerçek hak durumunu yansıtmayan sicil ile maddi hukuk arasındaki farklılığın açıklayıcı bir tescille ortadan kaldırılması sağlanacaktır. O halde maddi hukuk bakımından hak sahibinin davacı eş olduğu ve mülkiyeti tescil talebinden önceki bir aşamada kazandığı kabul edilmekte, fakat boşanma kararının içeriği haline gelmiş protokolün ilgili hükmünün "tescil” sözcügünü içermemesi nedeniyle ilgili müdürlükçe tescil işleminin yapılmasından kaçınılmaktadır. $\mathrm{Bu}$ çelişkili hukuki sonucu kabul etmeye imkân bulunmamaktadır.

Davacı eşin mülkiyet hakkını kesinleşmiş boşanma kararı nedeniyle kazandığı kabul edilmemekte ve açıklayıcı tescil işleminin yapılmasından kaçınılmakta ise, davacıya, açması tavsiye edilmesi gereken dava TMK m. 716/I hükmü olabilirdi. Eğer bahsi geçen hukuki görüşte "tapu iptal ve tescil davası" ifadesi ile kast edilen, TMK m. 716'daki tescile zorlama davası ise, bu ihtimalde de çelişki yaratan durum, boşanma protokolünün varlığına, geçerliliğine ve bu protokolün hukuki anlamda etki ve sonuç doğuracağına

71 Oğuzman/Seliçi/Özdemir, N. 260; Sirmen, Lale (2017) Eşya Hukuku, 5. Baskı, Yetkin Yayınları, Ankara, s.225 vd. 
inanarak boşanan ve protokol uyarınca bir ayni veya şahsi hakkın alacaklısı durumunda olan eşin, hâkimin protokolü uygun bulmuş olmasına rağmen kısa kararı yeterince özenli bir biçimde kaleme almamış olması nedeniyle alacağına kavuşamamasıdır. Borçlu durumdaki eş ise hem boşanma davasından beklediği birincil sonuç olan "boşanma ilamı"na kavuşmuş, hem de onun yukarıda bahsi geçen örneklerde olduğu gibi, protokol gereğince borçlanmış olduğu edimi yerine getirmekten kaçınmasına imkân tanınmış olmaktadır. Yargıtay'ın eski tarihli bir kararında ${ }^{72}$ kısa kararda boşanma protokolüne ilişkin hüküm bulunmayıp gerekçede protokole yer verilmesi, örtülü onay olarak nitelendirilmiş, kocanın bir yandan boşanma sonucunu elde edip diğer yandan protokol hükümlerinin geçersiz olduğunu ileri sürmesi dürüstlük kuralına aykırı bulunmuştur.

O halde, hukuki görüş bildirilen olayda, boşanma protokolünün "devir" ifadesini içermeyen lafzı değil, protokolün, uygun biçimde kısa kararın içeriği haline gelmemiş olması sorun teşkil etmektedir. Davacı eşin böyle bir durumda bir taraftan kararın eki haline gelmiş bulunan fakat icra kabiliyeti bulunmayan boşanma protokolü ile hukuki sonuca "tescile zorlama" davası açarak erişmesi gerekirken öte taraftan bu yönde uygulama gelişmesi, kişilerin ayni haklarını tehlikeye düşürmekte, bu haklara erişimi güçleştirmekte ve hukuk devleti ilkesine zarar vermektedir. Ortaya çıkan sonuç, kişileri, ayni haklarını elde edebilmek için ikinci bir dava açmaya, yeniden yargılama masrafı yapmaya mecbur birakmaktadır.

\section{Protokolde Vade Kararlaştırılması Halinde}

Anlaşmalı boşanma davalarında sıklıkla karşılaşılan durumlardan biri de eşlerden birine ait taşınmazın mülkiyetini diğerine geçiren ya da bir eş lehine sınırlı ayni hak kurulmasını içeren protokol hükümlerinde ifa zamanı olarak boşanma kararının şekli anlamda kesinleşmesinden sonraki bir zamanın kararlaştırılmasıdır. Eşler mülkiyetin devrini veya sınırlı ayni hakkın kurulmasını, bir takvim günü olarak belirleyebilecekleri gibi, belirli bir

72 Bkz. Yargitay 2. Hukuk Dairesi, E: 1995/925, K: 1995:1772, T: 14.02.1995. Kararın ilgili kısmının metni için bkz. Özdemir, s. 224. 
sürenin geçmesine dayalı olarak da belirleyebilirler. Bu şekilde kararlaştırılan vadenin $^{73}$ kısa kararda yer bulması halinde nasıl icra edileceği sorun teşkil etmektedir. Öğretide, oldukça istisnai bazı hallerde vadesi gelmemiş, gelecekte yerine getirilecek alacaklar için eda davası açılabileceği ileri sürülmektedir ${ }^{74}$. Bir yargılama faaliyeti sonucunda elde edilmiş eda hükmünün ise ilamlı icraya konu olabilecek açıklıkta olması gerekmektedir. İlamı yerine getirecek olan icra veya tapu memurunun tereddüte düşmemesi, hükmü yorumlamak zorunda kalmaması gerektiği bilinmektedir ${ }^{75}$. Hâlbuki, boşanma hükmünün içeriği haline gelen protokolde mülkiyetin devri veya sınırlı ayni hakkın kurulması için bir vade kararlaştırıldığında, kararın şekli anlamda kesinleşmesi anında henüz vade gelmemiş olabilir. Dahası, söz konusu vade belirli ya da belirlenebilir nitelikte olmayabilir. İşte bu olasılıkta, mülkiyetin veya sınırlı ayni hakkın kazanılması, tescilsiz kazanma hallerinden olan mahkeme kararı (TMK m. 705/II) ile gerçekleşememektedir. Öte yandan, böylesi bir boşanma hükmünün eşlerden birine mülkiyeti devir veya sınırlı ayni hak kurmaya ilişkin bir "yükümlülük yüklediği" kabul edilirse, bu yükümlülük, söz konusu vade dolmuş olmasına rağmen yerine getirilmediği takdirde alacaklı eşe ikinci bir dava açmaktan başka bir hukuki yol bırakılmamış olmaktadır. Bu dava da TMK m. 716/II hükmüne dayanan ve davacının, mahkemeden mülkiyetin kendisine geçirilmesini veya lehine sınırlı ayni hakkın kurulmasını talep ettiği bir davadır ${ }^{76}$.

Konuya ilişkin bir Yargıtay kararı" uyarınca da "Boşanma ilamında tescilin davacı adına yapılabilmesi için hükmün 4. maddesine 'Taraflar arasındaki anlaşma uyarınca davacı tarafin maddi ve manevi tazminat taleplerinin karşılı̆̆ı olarak tapu sicilinde davalı adına tescilli bulunan A1.

73 "Vade" terimi ile ilgili ayrıntılı bilgi için bkz. Bilgin Yüce, Melek (2015) Alacaklı ve Borçlu Açısından İfa Zamanı, Vedat Kitapçılık, İstanbul, s. 47.

74 Bkz. Pekcanıtez, C. II, s. 967. Yazar, dönemsel edimlere ilişkin alacakları ve nafaka alacaklarını örnek olarak göstermektedir.

75 Pekcanitez, C. II, s. 971.

76 Oğuzman/Seliçi/Özdemir, N. 1501.

77 Bkz. Yargitay 1. Hukuk Dairesi, E:2011/5893, K:2011/6616, T: 02.06.2011, kararın tam metni için bkz. <https:/www.lexpera.com.tr/ictihat/yargitay/1-hukuk-dairesi-e-2011-5893k-2011-6616-t-02-06-2011> s.e.t: 09.10.2019. 
parsel sayılı 1024/2400 arsa payl 2532.63 metrekare yüzölçümlü taşınmazın üzerindeki devir yasağı kalktığı gün mesai saati bitimine kadar herhangi bir bedele bağlı olmaksızın davalı tarafından tapu sicilinde davacıya devir edilmesine’ ibaresi konulmuştur. Ancak devir yasă̆ı süresi dolduğu halde davalının tapuya giderek devri yapmadiğı anlaşılmaktadır. Bu durumda başka türlü davalının tapuya giderek işlemi yapmasını sağlayacak zorlayıcı bir yol bulunmamaktadır." ifadeleriyle, tapuda devir işleminden kaçınan davalıyı devre zorlamak için ikinci bir dava açılması gerektiği sonucuna varılmıştır.

$\mathrm{O}$ halde, eşlerden birine ait taşınmazın mülkiyetini diğerine devretmenin ya da bir eş lehine sınırlı ayni hak kurulmasını içeren, hâkim tarafından uygun bulunmuş protokol hükümlerinde vade kararlaştırılmışsa, boşanma kararının şekli anlamda kesinleşmesi, ayni hakkın tescilsiz olarak kazanılması için yeterli değildir. Tapu sicil müdürlüklerinde, söz konusu mahkeme kararı duraksamaya yer vermeden icra edilebilecek nitelikte olmadığı için tescil işleminden kaçınılmakta, alacaklı eşe, ikinci bir dava açmaktan başka bir yol kalmamaktadır. Hükmün, taşıması gereken özelliklerden uzak olması ve alacaklı eşin ikinci bir dava açması zorunluluğundan ibaret hale gelen bu soruna hukuk sistemi içinde bir çözüm üretilmesi gerekmektedir. Kanaatimizce de, vadenin kararlaştırıldığı bu gibi yükümlülüklerin yer aldığı boşanma karalarında alacaklı eş, mülkiyeti veya sınırlı ayni hakkı, mahkeme kararının kesinleşmesiyle tescilden önceki bir aşamada kazanamamaktadır. Zira tapu sicil hukukunun en temel ilkelerinden biri, şarta veya vadeye bağlı tapu sicil işleminin yapılamamasıdır ${ }^{78}$. Protokolde belirlenen vadenin gelmesine rağmen borçlu eş tescil talebinde bulunmaktan kaçınırsa ikinci bir dava açılması gerekmektedir. Nitekim yargı uygulaması da bu yönde gelişmiştir.

\section{3. İfadan Kaçınmanın Hukuki Sonucu}

a. Açılması Gereken Davanın Hukuki Niteliği

Eşlerden birine ait taşınmazın mülkiyetini diğerine geçiren ya da bir eş lehine sınırlı ayni hak kurulmasını içeren boşanma protokolünün hâkim

78 Bkz. Tapu Sicil Tüzüğü m. 16/II. Bkz. RG T:17.08.2013, S:28738. 
tarafından uygun bulunmuş fakat kısa kararda protokol hükümlerine açıkça yer verilmeyip yollama yapılmakla yetinilmişse, ayni hakkın tescilsiz olarak (mahkeme kararıyla) kazanılamadığı belirtilmişti. Böyle bir durumda devir borçlusu eş, tapuda ferağa yanaşmazsa alacaklı eşin ikinci bir dava açmaktan başka bir seçeneği kalmamakta idi. Bu davanın hukuki niteliği ise TMK m. 716/I hükmüne dayanan "tescile zorlama davası" dır ${ }^{79}$.

Taşınmazın mülkiyeti ya da taşınmaz üzerindeki sınırlı ayni hak, bu ikinci dava sonucunda verilen kararın kesinleşmesiyle, tescilden önce diğer eşe geçer $^{80}$. Dolayısıyla, tapuda yapılan tescil, kurucu değil, açıklayıcı niteliktedir. Benzer şekilde, eşlerden birine ait taşınmazın mülkiyetini diğerine geçiren ya da bir eş lehine sınırlı ayni hak kurulmasını içeren boşanma protokolünün vade içermesi durumunda da vade tarihi gelmiş olmasına rağmen borçlu eş tapuda ferağa yanaşmazsa, bu tarihten sonra alacaklı eşin izlemesi gereken yol aynidır ve tescile zorlama davasının neticesinde ayni hak tescilsiz olarak kazanılmaktadır.

Boşanma kararının kesinleşmesinden sonra fakat tescile zorlama davasının açılmasından önceki bir zamanda taşınmazın mülkiyeti veya taşınmaz üzerindeki sınırlı ayni hak, devir borçlusu eş tarafından protokol

79 Bkz. Yargitay 8. Hukuk Dairesi, E: 2014/9251, K: 2014/20692, T: 11.11.2014. Karara göre “2. Aile Mahkemesi'nin 2007/376-545 Esas ve Karar sayılı boşanma dosyasında taraflarca düzenlenen boşanma protokolünün 6. bendiyle davalı ... adına kayıtlı 3020 parsel üzerindeki 28 nolu bağımsız bölümün kararının kesinleştiği tarihten itibarına 1 aylık süre içerisinde davacı ...'e devredileceği kararlaştırıldığına, söz konusu protokol Mahkemece uygun bulunarak onaylandığına, boşanma kararı kesinleşmesine rağmen protokolde öngörülen süre içerisinde taşınmazın devredilmediği anlaşıldığına, her ne kadar dava dilekçesinde tapu iptali ve tescil istenilmiş ise de, sslah edilmek suretiyle dava bedele dönüştürüldügüne, tapu kaydı üzerindeki ipotek ile icra takibinden kaynaklanan kayıt ve kısıtlamalar dikkate alındığında, davacının protokol gereği ayın olarak belirlenen talebini bedele dönüştürmekte hukuki yararının bulunduğu hususunda duraksamamak gerektiğine göre, mahkemece bedele dönüştürülen davanın kabulüne karar verilmiş olmasında bir isabetsizlik görülmemiştir.”. Kararın tam metni için bkz. <https://www.lexpera.com.tr/ictihat/yargitay/8-hukuk-dairesi-e-2014-9251-k-2014-20692t-11-11-2014> s.e.t: 06.12.2019. Kararda, açılması gereken bu dava "tapu iptal ve tescil davası" olarak adlandırılmaktadır.

Eren, 2016, s. 252. 
gereğince alacaklı olan eş veya üçüncü kişi haricinde bir başkasına devredilir veya kurulursa, artık bu kişiye karşı boşanma protokolüne dayanarak tescile zorlama davası açma imkânı kalmamaktadır. Böyle bir olasılıkta açılabilecek dava, devir borçlusu eşe karşı sözleşmeye aykırılıktan kaynaklanan bir tazminat davası (TBK m. 112 vd.) olabilir. Böyle bir engelle karşılaşmamak adına alacaklının, ihtiyati tedbir talep ederek taşınmazın sayfasına TMK m. 1010/I, b. 1 uyarınca çekişmeli hakların korunmasına ilişkin şerh konulmasını talep etmesi faydalı olur ${ }^{81}$. Bu şerh sayesinde alacaklının kişisel hakkı güvence altına alınarak sonradan bu şerhe rağmen taşınmaz üzerinde hak sahibi olan kişilere karşı da ileri sürülebilir ${ }^{82}$. Şerh, mahkeme kararıyla değil, şerhin tapu siciline yapılmasıyla birlikte etki göstermektedir ${ }^{83}$.

\section{b. Görevli ve Yetkili Mahkeme}

Boşanma kararının eki niteliğindeki boşanma protokolünün eşlerden birine ait taşınmazın mülkiyetini diğerine geçiren ya da bir eş lehine sınırlı ayni hak kurulmasını içeren hükmünün gereği olarak tapuda ferağa yanaşmayan borçlu eşe karşı açılan tescile zorlama davasına bakmakla görevli ve yetkili mahkemenin tespiti önem taşımaktadır. Hükümde açıkça yer almayan, fakat hâkim tarafından uygun bulunup kararda yollama yapılan protokol hükümleri gereğince tapuda ferağa yanaşmayan eş aleyhine açılacak davalarda görevli mahkeme belirlenirken iki farklı görev kuralından hangisinin uygulanması gerektiği belirlenmelidir. Bilindiği gibi "tapu iptal ve tescil davası” olarak yanlış adlandırılan tescile zorlama davası malvarlığına ilişkin davalardandır. 6100 sayılı Hukuk Muhakemeleri Kanunu m. 2/I uyarınca "Dava konusunun değer ve miktarına bakılmaksızın malvarlığı haklarına ilişkin davalarla, şahıs varlığına ilişkin davalarda görevli mahkeme, aksine bir düzenleme bulunmadıkça asliye hukuk mahkemesidir.”. Bu hüküm

81 Anlaşmalı boşanma yargılamasının çekişmesiz yargı faaliyeti kapsamında değerlendirilmesinin çekişmeli hakların tapu siciline şerhi ile ilişkisi hakkında değerlendirmeler için bkz. Atmaca Ülkü, s. 176.

Doğan, Murat (2004) Tapu Sicilinde Tasarruf Yetkisi Kısıtlamasının Şerhi, Seçkin Yayıncilik, Ankara, s. 141-142.

Doğan, s. 142. 
gereğince, davaya bakmakla görevli mahkemenin asliye hukuk mahkemesi olduğu sonucuna ulaşılabilir. Öte yandan, 4787 sayılı Aile Mahkemelerinin Kuruluş, Görev ve Yargılama Usullerine Dair Kanun'un 4. maddesi uyarınca, “...Türk Medenî Kanununun Üçüncü Kısım hariç olmak üzere İkinci Kitabı ile 3.12.2001 tarihli ve 4722 sayll Türk Medenî Kanununun Yürürlüğ̈̈ ve Uygulama Şekli Hakkında Kanuna göre aile hukukundan doğan dava ve işler..." aile mahkemelerinde görülür. Boşanma kararının eki haline gelmiş boşanma protokolünden doğan devir borcunun yerine getirilmemesi nedeniyle açılan dava, boşanmanın hukuki sonuçları arasında değerlendirilerek aile mahkemelerinin görevli olduğu sonucuna ulaşılmaktadır. Konuya ilişkin Yargıtay içtihatları da bu yönde oluşmuştur. Yüksek Mahkeme, "Uyuşmazlı, boşanma protokolüne dayalı olarak açılan tapu iptali ve tescil istemine ilişkin olup, Türk Medenî Kanununun ikinci kitabından kaynaklanmaktadır. Buna göre davanın aile mahkemesince görülüp sonuçlandırılması gerekmektedir." ifadeleriyle, sorunu aile hukukundan doğan bir uyuşmazlık olarak nitelendirmektedir ${ }^{84}$. Benzer şekilde boşanma protokolünden kaynaklanan intifa hakkının tescili talebiyle açılan davaya bakmakla görevli mahkeme, aynı gerekçe ile aile mahkemesi olarak tespit edilmiștir ${ }^{85}$.

Kanaatimizce aile mahkemesinin görevli olduğunu kabul etmek isabetli değildir. Boşanma kararının şekli anlamda kesinleşmesi ile inşaî etki doğar ve boşanma sonucu gerçekleşir. Bundan sonra açılan tescile zorlama davasının özünde malvarlığına ilişkin bir talep yer almaktadır. Eşler arasındaki her türlü

84 Bkz. Yargitay 20. Hukuk Dairesi, E: 2016/2065, K: 2016/4743, T: 19.4.2016. Kararın tam metni için bkz. <https://www.lexpera.com.tr/ictihat/yargitay/20-hukuk-dairesi-e-20162065-k-2016-4743-t-19-4-2016> s.e.t: 11.12.2019. Yüksek mahkeme, boşanma protokolünden kaynaklanan limited şirket payı devrine ilişkin borcun ifa edilmemesi nedeniyle açılan pay devri ve tescili talebiyle açılan davaya bakmakla görevli mahkemenin asliye ticaret mahkemesi değil, aile mahkemesi olduğuna hükmetmiştir. Konuya ilişkin bkz. Yargitay20. Hukuk Dairesi, E: 2015/14878, K: 2015/13172, T: 24.12.2015. Kararın tam metni için bkz. <https://www.lexpera.com.tr/ictihat/yargitay/20-hukuk-dairesi-e-201514878-k-2015-13172-t-24-12-2015> s.e.t:11.12.2019.

85 Bkz. Yargitay2. Hukuk Dairesi, E: 2016/9085, K: 2017/11878, T: 30.10.2017. Kararın tam metni için bkz. <https:/www.lexpera.com.tr/ictihat/yargitay/2-hukuk-dairesi-e-2016-9085k-2017-11878-t-30-10-2017> s.e.t:12.12.2019. 
uyuşmazlık için aile mahkemeleri görevli olarak kabul edilmeyip ${ }^{86}$, talebin içeriğinin aile hukukundan kaynaklanıp kaynaklanmadığı dikkate alınırken, artık aralarındaki evlilik birliği sona ermiş kişiler arasındaki malvarlığına ilişkin taleplere bakmakla görevli mahkemenin aile mahkemesi olduğu görüşüne katılmaya imkân bulunmamaktadır. Boşanma protokolüne istinaden açılan tescile zorlama davasının malvarlığına ilişkin dava olarak değerlendirilmesi gerektiği ve görevli mahkemenin asliye hukuk mahkemesi olduğu kanaatindeyiz. Zira bu yaklaşım, yetkili mahkemenin tespiti bakımından da tutarlı bir sonuca ulaşılmasını sağlayacaktır. Tescile zorlama davasının konusu olan ayni hakkın, boşanmanın fer'i sonuçlarından birine ilişkin olduğu kabul edilirse, yetkili mahkeme belirlenirken bu devrin hukuki sebebinin de araştırılması gerekecektir. Örneğin, eşlerden biri yoksulluk nafakası talep etmeme karşıllı̆ında taşınmaz üzerinde bir ayni hak kazanmayı tercih etmişse; yetkili mahkeme nafaka alacaklısı eşin yerleşim yeri mahkemesi olarak tayin edilecekken (TMK m.177); mal rejiminin tasfiyesi kapsaminda ayni hakkın devri borçlanılmışsa TMK m. 214'e göre yetkili mahkeme tayin edilecektir. Oysa, bu talep aile hukukundan kaynaklanan bir uyuşmazlık olarak değil de malvarlığına ilişkin münferit bir talep olarak nitelendirilirse, yetkili mahkemenin tespiti de daha tutarlı biçimde gerçekleşir. Açılacak tescile zorlama davası taşınmazın aynına ilişkin veya ayni hak değişikliğine yol açacak bir dava olduğu için, yetkili mahkeme de HMK m. 12 uyarınca taşınmazın bulunduğu yer mahkemesi olmalıdır ${ }^{87}$. Birden fazla taşınmazın bulunduğu hallerde ise her bir taşınmazın bulunduğu yer mahkemesi yetkili olup bunlar arasında seçim yapma hakkının davacıya ait olduğu kabul edilmektedir ${ }^{88}$.

\footnotetext{
86 Akkan, Mine (2017) Pekcanitez Usul Medeni Usul Hukuku C. I, 15. Bası, On İki Levha Yayınları, İstanbul, s. 203; Akkaya, s. 264.

87 Taraflar arasındaki bir sözleşme bir ayni hakkın tescil ve tesisi yükümlülüğü doğuruyor ise böyle bir sözleşmenin ifasını sağlama amacına yönelik davaların da HMK m. 12 kapsamında değerlendirilmesi gerektiği yönünde bkz. Aydemir Karademir, Dilek (2019) Medeni Usul Hukukunda Mahkemelerin Yetkisi, 2. Baskı, Ankara, s. 314; taşınmazlar üzerindeki ayni hakka veya ayni hak değişikliğine ilişkin davalarda yetki hakkında ayrıntılı bilgi için bkz.s. $322 \mathrm{vd}$.

Aydemir Karademir, s. 357.
} 


\section{c. Tescile Zorlama Davasının Tabi Olduğu Zamanaşımı}

Boşanma kararının eki niteliğindeki boşanma protokolünün eşlerden birine ait taşınmazın mülkiyetini diğerine geçiren ya da bir eş lehine sınırlı ayni hak kurulmasını içeren hükmünün gereği olarak tapuda ferağa yanaşmayan borçlu eşe karşı açılan tescile zorlama davasının tabi olduğu zamanaşımı süresinin tespiti, bu alacağın niteliğinin tespiti ile mümkündür.

Tescile zorlama davası, evliliğin boşanma sebebiyle sona ermesinden doğan bir dava hakkı olarak nitelendirilecek olursa, bu hak TMK m. 178 uyarınca boşanma hükmünün kesinleşmesinin üzerinden bir yıl geçmekle zamanaşımına uğrar. Fakat bu dava, boşanma protokolünden kaynaklanan bir edimin yerine getirilmemesi sebebiyle açılmış bağımsız bir dava olarak nitelendirilirse, TMK m. 178 hükmü uygulama alanı bulmaz ${ }^{89}$. Dolayısıyla Türk Borçlar Kanunu'nun zamanaşımına ilişkin hükümleri uygulanmalıdır. Kanaatimizce de bu dava, boşanmanın fer'i sonuçlarına ilişkin bir dava olarak nitelendirilmemelidir. Tescile zorlama davasının konusu ne bir tazminat ne de nafaka alacağıdır. Bu nedenle boşanma protokolünün gereği olarak ferağa yanaşmayan eşe karşı açlan tescile zorlama davası, özünde sözleşmeden

89 TMK m. 178 hükmünün gerekçesinde yer alan "Madde boşanma sebebiyle açılacak davaların, evliliğin boşanma nedeniyle son bulmasından itibaren bir yıllık zamanaşımı süresine tabi olduğunu hükme bağlamaktadır. Bu hüküm sayesinde evliliğin boşanma nedeniyle son bulmasına rağmen eşlerin yıllar sonra maddî ya da manevî tazminat ya da ilk kez istenilen yoksulluk nafakası dolayısıyla karşı karşıya gelmeleri önlenmek istenmiştir. Bütün alacak istemleri gibi boşanmadan doğ an tazminat ve yoksulluk nafakası istemlerinin de bir zamanaşımı süresinin olması gerekir. Bu süre, evliliğin boşanma sebebiyle son bulmasına ilişkin hükmü $n$ kesinleşmesinden itibaren işlemeye başlayacaktır." ifadelerden, 1 yıllık zamanaşımı süresinin boşanmanın sonuçlarından maddi ve manevi tazminat ile nafakaya ilişkin açılacak davalar bakımından öngörüldüğü anlaşılmaktadır. Gerekçe için bkz.

<https://www.tbmm.gov.tr/tutanaklar/TUTANAK/TBMM/d21/c073/tbmm21073011ss072 3.pdf>, s.e.t.: 14.05.2020. Öğretide bu hükmün boşanmanın bütün fer’i sonuçlarına ilişkin olarak açılacak davalarda uygulanması gerektiği yönünde bkz. Dural/Öğüz/Gümüş, N. 823; Öztan, s. 856. Edinilmiş mallara katılma alacağının tasfiyesinde katılma alacağına ilişkin talebin tabi olduğu zamanaşımı süresinin 10 yıl olduğu yönünde bkz. Yargıtay Hukuk Genel Kurulu, E: 2016/8-1061, K: 2016/959, T: 5.10.2016, kararın tam metni için bkz. $<$ https://karararama.yargitay.gov.tr/YargitayBilgiBankasiIstemciWeb/>, s.e.t: 15.5.2020. 
kaynaklanan borcun ifasına ilişkin bir talebi içerdiği için on yıllık zamanaşımı süresi uygulanmalıdır ${ }^{90}$. Boşanma protokolünde mülkiyet hakkının devri değil de, sınırlı ayni hakların kurulması borçlanılmışsa, bu talepler de on yıllık zamanaşımı süresine tabi olmalıdır ${ }^{91}$. Bu durumda TBK m. 146 hükmü gereğince on yıllık zamanaşımı süresi, borcun muaccel olmasından itibaren işlemeye başlar ${ }^{92}$.

\section{KAZANDIRMANIN ÜÇÜNCÜ KIşi̇ LEHİNE YAPILMASI HALİNDE}

Anlaşmalı boşanma müzakerelerinde eşlerin üçüncü kişi lehine kazandırmada bulunmaları, sıklıkla karşılaşılan bir durumdur. Eşler, boşanma anlaşmasında birine veya her ikisine ait taşınmazın mülkiyetinin üçüncü kişiye devrini veya taşınmaz üzerinde üçüncü kişi lehine sınırlı ayni hak kurulmasını kararlaştırabilirler. Lehine kazandırmada bulunulan üçüncü kişi genellikle eşlerin ortak çocukları olabilmektedir. Boşanma protokolünün hâkim tarafından uygun bulunarak hükmün içeriği haline gelmesi mümkündür. Bununla birlikte, hükümde protokole yollama yapılmakla yetinilmesine uygulamada sıklıkla rastlandığına değinilmişti ${ }^{93}$. Hukuki sorunlar da esas olarak bu ikinci olasılıkta ortaya çımaktadır. Hâkim tarafından uygun bulunan boşanma protokolünde eşlerden birine ait taşınmazın mülkiyetinin üçüncü kişiye devri veya taşınmaz üzerinde üçüncü kişi lehine sınırlı ayni hak kurulması vaat edilmiş olabilir. Öncelikle bu vaatlerin hukuki niteliği, sonrasında tapuda tescile yanaşmayan (borçlu) eşe karşı başvurulabilecek hukuki yollar tespit edilmelidir.

Bilindiği gibi, borç ilişkisi kural olarak tarafları arasında hüküm ve sonuç doğurur. Fakat istisnaî bazı hallerde borç ilişkisi, ilişkinin dışındaki

\footnotetext{
90 Konuya ilişkin ayrıntılı açıklamalar için bkz. Erdem, Mehmet (2010) Özel Hukukta Zamanaşımı, On İki Levha Yayınları, İstanbul, s. 42.

91 Erdem, s. 42.

92 Erdem, s. $162 \mathrm{vd}$.

93 Bkz. IV, B, I.
} 
kişiler bakımından da hüküm doğurmaktadır ${ }^{94}$. Sözleşmeden doğan borç ilişkilerinde ifanın üçüncü kişilere gerçekleştirilmesi kararlaştırılabilir. Boşanma protokolünde de üçüncü kişiye ayni hak devredileceğine ilişkin taahhütler, edimin üçüncü kişiye gerçekleştirilmesinin öngörüldügü "üçüncü kişi yararına sözleşme” örneği olarak ortaya çıkmaktadır (TBK m. 129). Devir borçlusu eş vaat eden, diğer eş vaat ettiren, üçüncü kişi de lehdar (yararlanan) durumundadır $^{95}$. Vaat ettirenin, üçüncü kişi yararına böyle bir sözleşme yaparak kazandırmada bulunmasının çeşitli sebepleri (causa) olabilir. Bunlar teminat sebebi, bağışlama sebebi, ifa sebebi veya alacak sebebidir ${ }^{96}$.

Üçüncü kişi yararına sözleşmeler, kural olarak eksik üçüncü kişi yararına sözleşme ve tam üçüncü kişi yararına sözleşme olmak üzere iki türlüdür. Bu iki sözleşme türü arasındaki temel farklılık, üçüncü kişinin ifayı talep yetkisine sahip olması bakımındandır ${ }^{97}$. Eksik üçüncü kişi yararına sözleşmelerde üçüncü kişi yararına bir alacak hakkı doğmamaktadır, bu nedenle de bu kişi, borçludan borcun ifasını isteme hakkına sahip değildir ${ }^{98}$. Fakat tam üçüncü kişi yararına sözleşmelerde üçüncü kişi, alacağ 1 doğrudan doğruya kazanmakta ve tek başına dahi ifasını talep edebilmektedir ${ }^{99}$. TMK m. 129 uyarınca üçüncü kişi yararına sözleşmeler kural olarak eksik üçüncü kişi yararınadır. Fakat tarafların iradesine, amacına, örf ve âdete (teamüle) uygun düştüğü ölçüde veya açık bir kanun hükmü bulunduğu hallerde tam üçüncü kişi yararına sözleşme ilişkisinin varlığ kabul edilir ${ }^{100}$. Üçüncü kişi yararına sözleşmenin kurulabilmesi için üçüncü kişinin iradesine veya rızasına ihtiyaç

94 Bkz. Oğuzman, M. Kemal/Öz, Turgut (2018) Borçlar Hukuku Genel Hükümler C. II, Vedat Kitapçılık, İstanbul, s. $441 \mathrm{vd}$.

95 Ayrıntılı açıklamalar için bkz. Akyol, Şener (1976) Tam Üçüncü Şahıs Yararına Sözleşme, Fakülteler Matbaası, İstanbul, s. 10 vd., Eren, Fikret (2018) Borçlar Hukuku Genel Hükümler, 23. Baskı, Yetkin Yayınları, Ankara. (Eren, 2018), s. 1169 vd.

Eren, Borçlar, s. 1174.

Oğuzman/Öz (2018), s. 443; Eren, 2018, s. 1172-1173.

Eren, 2018, s. 1174.

Akyol, s. 24 vd, Oğuzman/Öz (2018), s. 445-446; Eren, 2018, s. 1174-1175. 
bulunmamaktadır ${ }^{101}$. Üçüncü kişi, kendi yararına böyle bir sözleşmenin kurulmasına engel olamaz; fakat edimi kabul etmeyebilir ${ }^{102}$.

Kural olarak borçlandırıcı işlemler üçüncü kişi yararına yapılabilmektedir. Tasarruf işlemleri ise üçüncü kişiler lehine yapılamamaktadır ${ }^{103}$. Fakat üçüncü kişi yararına sözleşmeler, üçüncü kişi lehine tasarruf işlemi yapma vaadi içeren sözleşmeler olarak akdedilebilir. Nitekim boşanma protokollerinde de bir taşınmaz üzerindeki mülkiyetin veya sınırlı ayni hakkın üçüncü kişiye devri veya üçüncü kişi lehine kurulması vaat edilmiş olabilir. Bu sözleşmelerin hukuki niteliğinin tam üçüncü kişi yararına sözleşme olduğu kanaatindeyiz. Zira boşanmak isteyen eşlerin dışında, başka birinin, çoğu kez ortak çocuğun bu kazandırmadan yararlanması amaçlanmakta ve bu şartla eşler boşanmaya razı olmaktadır. Dolayısıyla lehine kazandırmada bulunulmak istenen üçüncü kişinin bir alacak hakkı doğmaktadır. Borçlu edimini yerine getirmezse, üçüncü kişi alacağı muaccel olur olmaz bunu borçludan doğrudan doğruya isteyebileceği gibi, gerektiğinde dava da açabilir ${ }^{104}$. Öğretide, borcun ifa edilmemesi durumunda vaat ettirenin de borcun ifa edilmemesine ilişkin hükümlere başvurabileceği kabul edilmektedir ${ }^{105}$. Hatta vaat ettirenin, edimin yerine getirilmemesi nedeniyle üçüncü kişinin uğradığı zararın tazminini talep edebileceği de ileri sürülmektedir ${ }^{106}$. Bu açıklamalardan hareketle, hâkim tarafından uygun bulunup kararda kendisine yollama yapılan boşanma protokolü uyarınca tapuda ferağa yanaşmayan, tasarruf işlemi yapmaktan kaçınan eşe karşı açılacak olan tescile zorlama davası hem eş hem de yararlanan üçüncü kişi tarafından açlabilmelidir. $\mathrm{O}$ halde borcun ifa edilmemesi durumunda vaat

\footnotetext{
101 Oğuzman/Öz (2018), s. 452.

102 Oğuzman/Öz (2018), s. 453.Böylelikle, üçüncü kişinin hak kazanmasındaki irade dışllık, bertaraf edilmiş olur. Ancak üçüncü kişi edimi reddetmişse, artık alacaklının borçluya karşı üçüncü kişiye ifanın gerçekleştirilmesi talebiyle bir dava açamayacağı kabul edilmektedir. Bkz. Akyol, s. 188 ve 204.

103 Ŏguzman/Öz (2018), s. 451-452.

104 Akyol, s. 176, Eren, 2018, s. 1179.

105 Oğuzman/Öz (2018), s. 455, dpn. 123. Vaat ettiren ile üçüncü kişi birlikte dava açarlarsa aralarında ihtiyari dava arkadaşlığının bulunacağı yönünde bkz. Akyol, s. 210.

106 Eren, 2018, s. 1186.
} 
ettirenin (devir borçlusu olmayan eşin) de borcun ifa edilmemesine ilişkin hükümlere başvurabileceği sonucuna ulaşılmaktadır ${ }^{107}$. Fakat davanın, ifanın üçüncü kişiye gerçekleşmesi talebini içermesi gerektiği kabul edilmektedir ${ }^{108}$. Açılan bu davanın olumlu sonuçlanması ile ayni hak mahkeme kararının şekli anlamda kesinleşmesi ile tescilsiz olarak kazanılır.

\section{DEĞERLENDİRME VE SONUÇ}

Evlilik birliğini sürdürmek istemeyen, hızlı, barışçl ve daha kolay biçimde boşanmak isteyen eşler, sıklıkla anlaşmalı boşanma yolunu tercih etmektedir. Bu yargılama faaliyetinde tarafların belirli nitelik ve içerikte ortaya koydukları iradeleri hâkim tarafından uygun bulunarak boşanma kararının içeriği haline gelir. Tarafların boşanma protokolünde birine ait taşınmazı diğerine veya üçüncü kişiye devretmesi yahut sınırlı ayni hak kurmayı borçlanması mümkündür. $\mathrm{Bu}$ gibi yükümlülükler içeren boşanma anlaşmalarının "hüküm" içinde ne şekilde yer aldığı son derece önem taşımaktadır. Esasen hâkimin, kararın hüküm fikrasında boşanma protokolüne açıkça yer vermesi veya sadece protokole yollama yapmakla yetinmesi ayni hakkın mahkeme kararı ile tescilsiz olarak kazanılıp kazanılmaması bakımından belirleyici niteliktedir. Yargı uygulaması, mahkeme tarafından verilen boşanma kararının hüküm fikrasında açıkça "tescil" ifadesi geçmedikçe ayni hakkın tescilsiz olarak kazanılamayacağ yönünde şekillenmiştir. Dolayısıyla kararda boşanma protokolüne yollama yapılmakla yetinilmesi, hükmün beklenen sonucu doğurmasını engellemektedir. Boşanma kararında protokole yollama yapılması halinde borçlu eşin tapuda ferağa yanaşmaması durumunda, alacaklı eşin veya üçüncü kişinin ikinci bir dava açarak ayni hakkı elde etmesinden başka bir hukuki yol kalmamaktadır. Bu hallerde alacaklı durumundaki eşin, TMK m. 716 gereğince tescile zorlama davası açması gerekir. Benzer bir durum boşanma protokolünde vade kararlaştırılmış olması halinde ortaya çıkar. Ayni hakkın devrine ya da kurulmasına ilişkin vade kararlaştırılan boşanma protokolü,

107 Ŏguzman/Öz (2018), s. 455.

108 Akyol, s. 208. 
boşanma kararında açıkça yer alsa dahi tapu müdürlüklerinin tescil işlemi yapabilmeleri için ikinci bir davanın açılması gerektiği kabul edilmektedir. $\mathrm{Bu}$ ihtimallerde açılan tescile zorlama davalarına bakmakla görevli mahkeme ise aile mahkemesi olarak kabul edilmektedir. Fakat kanaatimizce boşanma hükmünün inşâ̂ etkisinin ortaya çıkmasıyla artık evlilik birliği sona eren kişilerin aralarındaki tescile zorlama davası, malvarlığına ilişkin bir dava olarak değerlendirilmeli, dolayısıyla taşınmazın bulunduğu yerdeki asliye hukuk mahkemesi tarafından görülmelidir.

Eşler, boşanma anlaşmasıında birine veya her ikisine ait taşınmazın mülkiyetinin üçüncü kişiye devrini veya taşınmaz üzerinde üçüncü kişi lehine sınırlı ayni hak kurulmasını kararlaştırabilirler. Hâkim tarafından uygun bulunup kararda kendisine yollama yapılan boşanma protokolü uyarınca tapuda ferağa yanaşmayan, tasarruf işlemi yapmaktan kaçınan eşe karşı açılacak olan tescile zorlama davası hem eş, hem de yararlanan üçüncü kişi tarafından açılabilmelidir.

Sonuç olarak, eşlerin aralarındaki ihtilafın sürmesini engellemek ve hızlı bir çözüme kavuşmak adına önem arz eden husus, boşanma protokolünün boşanma kararının içeriği haline gelmesinde hâkimin üstlenmesi gereken aktif roldür. Özellikle boşanma protokolünün zorunlu içeriğine ilişkin konularda hâkimin açık, anlaşılır, icra edilebilir nitelikte bir hüküm elde edinceye kadar tarafları anlaşmaya teşvik etmesi ve eşlerin üzerinde anlaştığı konuları uygun buluyorsa boşanma hükmünün içeriği haline getirmesi gerekir. İcrası mümkün olmayan bir protokolün yaratacağı hukuki sorunların, protokolün kararın sadece "eki" haline getirilerek daha da içinden çıkılmaz hale getirilmesi ne tarafların menfaatiyle ne de usul ekonomisi ilkesiyle bağdaşır. $\mathrm{Bu}$ nitelikleri taşımayan bir boşanma anlaşmasını uygun bulmasına rağmen icra edilebilir açıllıkta ve kesinlikte hüküm tesis etmeyen hâkimin hukuki sorumluluğuna başvurulmalıdır. 


\section{KAYNAKÇA}

Akıntürk, Turgut/ Ateş, Derya (2018) Türk Medeni Hukuku Aile Hukuku İkinci Cilt, Beta Yayınevi, İstanbul.

Akkan, Mine (2017) Pekcanıtez Usul Medeni Usul Hukuku C. I, 15. Bası, On İki Levha Yayınları, İstanbul.

Akkaya, Tolga (2017) Medeni Usul Hukuku Bakımından Boşanma Davası, Yetkin Yayınları, Ankara.

Akyol, Şener (1976) Tam Üçüncü Şahıs Yararına Sözleşme, Fakülteler Matbaası, İstanbul.

Arbek, Ömer (2005) "Boşanmanın Mali Sonuçları”, Ankara Üniversitesi Hukuk Fakültesi Dergisi, C: 54, S: 1, s. 115-163.

Atalı, Murat (2017) Pekcanitez Usul Medeni Usul Hukuku C. III, 15. Bası, On İki Levha Yayınları, İstanbul.

Atmaca Ülkü, Hande (2017) "Türk Hukukunda Anlaşmalı Boşanma Protokolü” (Doktora), Yeditepe Üniversitesi, Sosyal Bilimler Enstitüsü.

Aydemir Karademir, Dilek (2019) Medeni Usul Hukukunda Mahkemelerin Yetkisi, 2. Baskı, Ankara.

Bilgin Yüce, Melek (2015) Alacaklı ve Borçlu Açısından İfa Zamanı, Vedat Kitapçılık, İstanbul.

Boran Güneysu, Nilüfer (2014) Medeni Usul Hukukunda Karar, Adalet Yayınevi, Ankara.

Budak, Ali Cem/Karaaslan, Varol (2017) Medeni Usul Hukuku, Adalet Yayınevi, Ankara.

Doğan, Murat (2004) Tapu Sicilinde Tasarruf Yetkisi Kısıtlamasının Şerhi, Seçkin Yayıncılık, Ankara.

Dural, Mustafa/Öğüz, Tufan/Gümüş, Mustafa Alper (2019) Türk Özel Hukuku Cilt III Aile Hukuku, 14. Bası, Filiz Kitabevi, İstanbul.

Edis, Seyfullah (1987) Medeni Hukuka Giriş ve Başlangıç Hükümleri, gözden geçirilmiş 3. Bası, Ankara Üniversitesi Hukuk Fakültesi Yayınları, Ankara.

Elçin Grassinger, Gülçin (1997) "Boşanma Davasında Eşlerin Boşanmanın Tali Sonuçlarına İlişkin Konularda Anlaşma Yapmaları ve Konu İle İlgili İsviçre Federal Mahkemesi Kararı", İstanbul Üniversitesi Hukuk 
Fakültesi Mecmuası Prof. Dr. Türkan Rado’ya Armağan Sayısı, C: 55, S: 3, s. 235-242.

Erdem, Mehmet (2010) Özel Hukukta Zamanaşımı, On İki Levha Yayınları, İstanbul.

Eren, Fikret (2016) Mülkiyet Hukuku, Gözden Geçirilmiş 4. Baskı, Yetkin Yayınları, Ankara. (Eren, 2016).

Eren, Fikret (2018) Borçlar Hukuku Genel Hükümler, 23. Baskı, Yetkin Yayınları, Ankara. (Eren, 2018).

Esener, Turhan (1951) "Boşanmanın Fer'i Neticelerine Dair Mukaveleler", Ankara Üniversitesi Hukuk Fakültesi Dergisi, C: 8, S: 3, s. 610-628.

Kılıçoğlu, Ahmet M. (2015) Aile Hukuku, Turhan Kitabevi, Ankara.

Oğuzman, M. Kemal/ Öz, Turgut (2019) Borçlar Hukuku Genel Hükümler C. I, Vedat Kitapçılık, İstanbul.

Oğuzman, M. Kemal/ Öz, Turgut (2018) Borçlar Hukuku Genel Hükümler C. II, Vedat Kitapçılık, İstanbul.

Oğuzman, M. Kemal/ Seliçi, Özer/ Oktay-Özdemir, Saibe (2017) Eşya Hukuku, 20. Baskı, Filiz Kitabevi, İstanbul.

Öncü, Özge (2017) "Eşlerin “Anlaşmalı Boşanma” Çerçevesinde Mal Rejiminin Tasfiyesine Yönelik Olarak Yaptıkları Anlaşmalar ve $\mathrm{Bu}$ Anlaşmaların Uygulamada Doğurduğu Sorunlar”, Dokuz Eylül Üniversitesi Hukuk Fakültesi Dergisi Prof. Dr. Şeref Ertaş'a Armağan Özel Sayı, C. 19, s. 793-835.

Önen, Ergun (1981) İnşaî Dava, Ankara Üniversitesi Hukuk Fakültesi Adalet Yüksek Okulu Yayınları, Ankara.

Özdemir, Nevzat (2003) “Türk Hukukunda Anlaşmalı Boşanma” (Doktora), İstanbul Üniversitesi Sosyal Bilimler Enstitüsü.

Özmen, Etem Saba/ Aydın, Gülşah Sinem (2014) “Tapu İptal Davası Olarak Yanlış Adlandırma İle Açılan Davalar (Tescili İsteme Davası/Yolsuz Tescilin Düzeltilmesi Davası", İstanbul Barosu Dergisi, C: 88, S: 6, s. 179-215.

Öztan, Bilge (2015) Aile Hukuku, 6. Bası, Turhan Kitabevi, Ankara.

Pekcanitez, Hakan (2017) Pekcanıtez Usul Medeni Usul Hukuku C. II, 15. Bası, On İki Levha Yayınları, İstanbul.

Pulaşılı, Hasan (1989) Şarta Bağlı İşlemler ve Hukuki Sonuçları, Dayınlarlı Yayınları, Ankara. 
Schwenzer, Ingeborg/ Fankhauser, Roland (2017) Scheidung Band I: ZGB / Band II: Anhänge, 3. Auflage, Stämpfli Verlag, Bern.

Seçer, Öz (2016) “Anlaşmalı Boşanmada Eşlerin Yaptıkları Anlaşma”, İnönü Üniversitesi Hukuk Fakültesi Dergisi, C: 7, S: 2, s. 259-286.

Sirmen, Lale (1992) Türk Özel Hukukunda Şart, Banka ve Ticaret Hukuku Araştırma Enstitüsü Yayınları, Ankara.

Sirmen, Lale (2017) Eşya Hukuku, 5. Baskı, Yetkin Yayınları, Ankara.

Tanrıver, Süha (1998) "Şarta Bağlı Hüküm Kavramı ve Verilip Verilemeyeceği Sorunu”, Banka ve Ticaret Hukuku Dergisi, C: 19, S: 4, s. 43- 50.

Ünal, Mehmet/Başpınar, Veysel (2017) Şeklî Eşya Hukuku, Güncellenmiş ve Genişletilmiş 9. Baskı, Savaş Yayınevi, Ankara.

Yılmaz Bilgin, Esra Pınar (2016) Türk Hukukunda Anlaşmalı Boşanma, On İki Levha Yayıncilık, İstanbul.

http://www.resmigazete.gov.tr

https://www.lexpera.com.tr

https://www.tkgm.gov.tr

https://www.tbmm.gov.tr/tutanaklar/TUTANAK/TBMM/d21/c073/tbmm210 73011ss0723.pdf

https://karararama.yargitay.gov.tr/YargitayBilgiBankasiIstemciWeb/ 